\title{
Kentsel Mekânın Üretim Ve Değerleme Süreçlerine Marksist Emek-Değer Kuramı'nın Uygulanması
}

\author{
Ahmet Burak Büyükcivelek ${ }^{1}$ \\ ORCID: 0000-0002-1760-1107
}

\section{Öz}

Kapitalist sistem içinde mekân, toplumsal yapıyı oluşturan güç ilişkilerinin bir yansıması olarak görülmekte ve bu ilişkiler çerçevesinde şekillenmektedir. Sistem, aynı zamanda mekân algısını ve mekâna yönelik yaklaşımları da etkileyerek mekânı ancak belirli bir düşünce sistemi içinde tartışmaya olanak sağlamaktadır. Bu kısıtı aşmak için başta Marksist düşünce olmak üzere pek çok alternatif düşünce sisteminden yararlanılmaktadır. Sunulan çalışma da Marksizm'den esinlenerek kullanılmakta olan "mekân üretimi" ve "mekânın metalaşması" kavramlarının ötesine geçmeyi amaçlamıştır. Marx'ın Emek-Değer Kurami'nın, üretilen mekânın değerlenmesi sürecine uygulanmasıyla sürecin üzerindeki "örtü" kalkmış, sürecin aktörleri ve aktörlerin katkı alanları farklı ölçeklerde tanımlanabilir hale gelmiştir. Bunun sonucunda aktörler ve aktörlerin mekân üretiminde ortaya koyduklar emek üzerinden kentsel ölçekte yeni bir mekânsal adalet kurgusunun ilk işaretleri gözlemlenebilmiştir. Çalışma kapsamında beş konut projesini içeren saha çalışması aracılı̆̆ılyla Emek-Değer Kuramı'nın mekân ve mekânsal değer üretim süreçlerine daha ayrıntılı bir biçimde uygulanması sağlanmıştır. Bahçelievler, Ankara'da bulunan beş konut projesi üzerinden konut üretim süreçlerinin çözümlenmesiyle ortaya çıkan aktör-emek ilişkisinin, düşünsel emeğin olası katkıların sinırlarken, fiziksel emeğin sömürülmesine ise daha çok olanak să̆ladığı görüşmüş̧ür. Konut üretim süreçlerinin emek-değer yaklaşımı çerçevesinde kurgulanması durumunda, başta yap güvenliği olmak üzere yenilikçilik, estetik değer, mekânsal kalite, mekânsal/çevresel bütünlük ve mekânsal sürekliliklerin sağlanması gibi pek çok alanda yeni düşüncelerin gelişmesine olanak sağlanabileceği öne sürülmüştür.

Anahtar Kelimeler: kapitalizm, mekân üretimi, mekânmn değerlenmesi, emek-değer kuramı, mekânsal planlama.

\footnotetext{
${ }^{1}$ Dr.Öğr.Üyesi, Orta Doğu Teknik Üniversitesi, E-mail: aburakb@metu.edu.tr idealkent @ Kent Araştırmaları Dergisi (Journal of Urban Studies) 


\title{
Application of Marxist Labour Theory of Value on the Processes of Production and Valuation of Urban Space
}

\author{
Ahmet Burak Büyükcivelek 2 \\ ORCID: 0000-0002-1760-1107
}

\begin{abstract}
Within the capitalist system, space is seen as a reflection and a product of power relations. Furthermore, the capitalist system enables the discussion of space under a defined system of thought that also affects the perceptions of space and approaches toward space. Different alternative thought systems, especially Marxism, is utilised to overcome this limit. The work presented here aimed to move beyond the concepts of "production of space" and "commodification of space" borrowed from Marxist thought. With the utilisation of Marx's Labour Theory of Value on the production and valuation of space, the "veil" covering the processes started to disappear, actors and their contributions at different scales became identifiable. As a result of this, the first signs of a new construct of spatial justice became observable. In this research, with the help of the field study covering five housing projects from Bahçelievler District in Ankara, it became possible to apply the Labour Theory of Value to the processes of space and spatial value production in a more detailed way. In the end, it is observed that conventional approaches to the valuation of the building leads to limitations on the possible contributions of intellectual labour and offers further possibilities of exploitation over physical labour. Instead, an approach emphasising labour-value relationship may provide opportunities for structural safety, innovativeness, aesthetical value, spatial quality, environmental/spatial integrity and spatial continuities.
\end{abstract}

Keywords: capitalism, production of space, valuation of space, labour theory of value, spatial planning.

\footnotetext{
${ }^{2}$ Assist. Prof. Dr., Middle East Technical University, E-mail: aburakb@metu.edu.tr

idealkent @ C Kent Araştırmaları Dergisi (Journal of Urban Studies)

http://idealkentdergisi.com

Geliş Tarihi Received Date: 29.04.2020 Kabul Tarihi Accepted Date: 15.04.2021
} 


\section{Çalışmanın Amacı ve Önemi}

Kentsel mekân sürekli bir değişim içindedir. Bu değişimi bir bağlam içine oturtmak ve bu bağlamı mantıksal çerçeve içinde yorumlamak başta kent planlama olmak üzere iktisat, toplumbilim, coğrafya gibi pek çok bilimsel disiplinin araştırma alanına girmektedir. Okumakta olduğunuz bu çalışma kapitalist tarzda gerçekleşen sermaye birikim süreçlerinin oluşturduğu bağlami ${ }^{3}$ referans kabul ederek mekân üretimini, mekânın edindiği değeri ve bu değerin hesaplanmasını tartışmayı amaçlamaktır.

Çalışmanın temel varsayımı kapitalist düzende mekânın üretimi ve değerlenmesi süreçleri ve bu yönde yapılan değerleme çalışmalarının kapitalist sistemin sürekliliğini sağlamak amacyyla süreçlere ilişkin pek çok bileşeni sistematik olarak dışarıda tutuğu, bazı bileşenleri ise toplumsal ve mekânsal önemleriyle ters orantılı şekilde göz önünde bulundurma eğiliminde olduğu üzerinedir.

Çalışmanın amacının ve öneminin belirtildiği bu bölümü, mekânın ve mekân üretiminin kapitalist sistem için önemine vurgu yapmayı amaçlayan ikinci bölüm izlemektedir. Bu öneme paralel olarak gerçekleşen değerleme süreçleri, süreçler içinde planlama kurumunun üstlendiği rol ve süreçlerin eleştirel değerlendirmesi çalışmanın üçüncü bölümünü oluşturmaktadır. Dördüncü bölüm, çalışmanın yöntemsel önerisi olan Emek-Değer Kuramı'nın sunumuna, kuramın olanaklarına ve kısıtlarına ayrılmıştır. Beşinci bölüm saha çalışması ve çalışma alanı üzerinde uygulanacak yöntemle ilişkilidir. Çıkarım ve tartışmalardan oluşan altıncı ve son bölüm ise var olan değerleme yaklaşımları çerçevesinde oluşan kısıtlara ve emek-değer temelli bir değerleme sürecinin sağlayabileceği olanaklara odaklanarak çeşitli araştırma ve politika önerileri sunmayı amaçlamaktadır.

\section{Kapitalist Düzende Mekân}

\section{Lefebvre Ve Mekân Üçlemesi:}

Lefebvre (1991, s.31) "her toplum kendi mekânını üretir" derken toplumsal yapıyı oluşturan ekonomik ilişkilerin belirleyici özelliğine dikkat çekmektedir. Ekonomik ilişkiler, ya da yine Lefebvre'in deyimiyle üretim süreçleri,

\footnotetext{
${ }^{3}$ Kapitalist sistemin farklı yorumları iktisadi politikaları şekillendirmektedir. Serbest piyasa kapitalizmi, devlet kapitalizmi ya da sosyal kapitalizm farklı dönemlerde farklı yerlerde uygulamaya konmuş kapitalizm türleridir. Yazı kapsamında kapitalist sistem, kapitalist düzen ya da yalnızca kapitalizm olarak değinilen kavramlar kapitalizmin en yalın ve temel durumuna gönderme yapmaktadır. Bu durum üretim araçlarının özel mülkiyet düzeninde sahiplenildiği, iktisadi etkinliklerin temel güdüsünün kar elde etmek olduğu ve aktörler arasındaki ilişkilerin rekabet koşullarınca belirlendiği bir iktisadi politikalar bütünü tarafından tanımlanmaktadır.
} 
toplumsal yapının sürdürülmesinde önemli bir yerde durmaktadır. Toplumsal ilişkiler bu temel üzerinden şekillenirken diğer yandan toplum, bu ilişkilerin ve ekonomik yapının sürdürülmesine yönelik mekânları üretir. Günümüzdeki üretim ilişkileri ve bu ilişkilerden doğan toplumsal yapı, küresel ya da ileri kapitalizmin şekillendirdiği bir yapıdır. Kapitalist üretim ilişkileri, kendi içinde taşıdığı ve sürekli yeniden ürettiği krizleri, toplumsal ve ekonomik adaletsizlikleri ve bunları ötelemeye, yavaşlatmaya çalıştığı yolları iktisadi olduğu kadar mekânsal araçlarla da uygulamaya koymaktadır.

Lefebvre'in (1991) mekân üretimi üzerine yaptığı çalışmalar ve tanımladığı mekânsal üçleme (triad), kapitalist üretim süreçlerinin mekânla ilişkisine ışık tutmaktadır. Lefebvre'e göre yaşadığımız mekân kapitalist üretim ilişkilerini ve bu ilişkilerden doğan güç dağılımını yansıtmaktadır. Devlet dediğimiz kurumla yakın ilişki içinde olan sermaye sınıfı, kendine uygun, kendi çıkarına göre düzenlenmiş bir mekânı kendi mekânsal pratiklerinden hareketle zihinlerinde canlandırıp talep etmektedir (algılanan mekân). Devlete bağlı çalışan teknokratlar (örneğin şehir plancıları ve mimarlar) bu talebi projelendirmekte, bir başka değişle mekânın diline tercüme etmektedirler (tasarlanan mekân). Bu yorumlama ile plan, proje ya da başka bir araçla kavramsallaştırılan mekân, var olan teknolojik ve toplumsal ilişkiler içinde uygulamaya konu olacak şekilde teknik dille temsil edilmektedir. Uygulama, pek çok yönden plan ve projelerden farklılaşmaktadır; çünkü uygulama koşulları ve kısıtlar tasarlayanın düşüncelerini tam olarak yansitmasına izin vermez. Dolayısıyla algılanan, tasarlanan ve uygulanan mekân arasında kuvvetli ilişkiler olmasına rağmen her biri birbirinden farklı özellikler sergilemektedir. Tüm bu farklılıklara rağmen mekân üretimi gerçekleşir. Sistemin sürekliliği için mekân üretimi gerçekleşmek zorundadır. Üretilen mekânın deneyimlenmeye, ya da yaşanmaya başlamasıyla (yaşanan mekânlar) mekân yaklaşımlarındaki uyumsuzluklar toplumsal boyuta taşınır. Bir yanda sermaye sınıfının talepleri, diğer yanda mekânı gündelik deneyimleyen kentlilerin beklenti ve gereksinimleri bir çatışma alanı yaratmaktadır. Sermaye, beklentileri doğrultusundaki mekânı üretebilmek için her türlü baskıyı mekâna yansıtır, kullanıcılar da güçleri oranında buna direnirler ya da boyun eğerler. Böylelikle mekân sürekli bir çatısmanın, mücadelenin hem alanı hem de aracı olmaktadır.

Lefebvre'in (1968) daha önceki çalışmalarında kent hakkı olarak kavramsallaştırdığ 1 yaklaşım kentlilerin bir yandan kentsel hizmetlerden yararlanmasına vurgu yaparken diğer yandan, belki de daha öncelikli olarak, kentlilerin kentsel gelişim süreçlerinde etkin rol oynamasının önemine değinmektedir. Günümüzde katılım süreçleriyle bir oranda gerçekleştirilmeye çalışılan 
"mekânın toplumsal üretimi" adaletsiz gerçekleşen güç dağılımına bağlı olarak kimi avantajlı grupların seslerinin daha kuvvetli duyurmasina olanak sağlarken kimi grupların ise toplumsal dezavantajını bu süreçlere de taşımakta, bu dezavantajlı grupları mekân üretiminde de görünmez kılmaktadır (Marcuse, 2015 ve Low, 2017).

\section{Castells ve Yeniden Üretimin Mekânlarn:}

Castells de $(1974,1978)$ Lefebvre'e benzer şekilde ancak farklılaşan bir vurguyla mekânın sermaye üretim süreçleri tarafından şekillenmesinin yarattığı olumsuzlukları incelemektedir. Yazara göre sermaye sınıfları mekânı, üretim süreçlerini sürdürmek ve kâr marjlarını artırmak amacıyla kullanmakta, mekânsal örüntüleri bu güdüyle şekillendirmektedir. Bunun karşısında yer alan işçi sınıfının temel güdüsü ise mekânı kendi yeniden üretim süreçlerini devam ettirmek amacıyla şekillendirmektir. Dolayısıyla sermaye ve işçi sınıfları arasındaki mücadelenin mekâna yansıması, mekânın üretiminde sermayenin mi yoksa emeğin mi yeniden üretileceğine ilişkin bir çatışma etrafında gelişmektedir.

Castells (1984), mekânın, kentlilerin çoğu zaman maddi kazanım amacı olmadan, yalnızca farklılaşan gereksinimleri çerçevesinde kentsel mekânı üretmek amaciyla verdikleri mücadeleleri de tarihsel bir bakış açısında değerlendirmiştir. Yakın geçmişte deneyimlenen Gezi Parkı olaylarının da çözümlenmesine bir oranda 1şık tutan bu çerçeve toplumsal hareketlerin kentle ilişkisini kuvvetli bir şekilde kurmaktadır. Merrifield'in (2002) Liverpool, Baltimore, Los Angeles ve New York kentlerinde yaptı̆̆ çalışmalarda yeni konut gelişim projelerinin dişlayıcı etkilerine ve bu projelere karşı verilen mücadelelere yer verilmektedir. Mitchell (2003) ise Amerika Birleşik Devletleri üzerine odaklanan çalışmalarında kamusal alanlar üzerine verilen mücadelelere vurgu yapmaktadır. Yazarın çalışmaları, Berkeley'deki People's Park'ın ve New York'ta evsizler tarafından kullanılan bir park alanının sermaye odaklarının çıkarlarıyla çelişen kullanımlar olmaları nedeniyle dönüştürülmelerine yönelik üretilen projeleri ve bu projelerin gerçekleşmemesi için verilen mücadeleleri konu almaktadır.

\section{Harvey ve Sermaye Döngüleri:}

Harvey'in (1973) kapitalist mekân üretim süreçlerine ilişkin yaptı̆̆ ilk çalışmalar kentsel mekân üretiminde oluşan adaletsizliklere odaklanmaktadır. Yazarın liberal çözümler olarak adlandırdığı kapitalist mekân üretim süreçleri, doğası gereği adaletsizlik üretmekte ve ekonomik düzlemede gerçekle- 
şen adaletsizlikleri mekâna da yansitarak, adaletsizliği daha da pekiştirmektedir. Harvey, sonraki çalışmalarında mekân üretim süreçlerine daha ayrıntılı biçimde odaklanmakta ve bunları siyasal iktisat bağlamında değerlendirmektedir.

Kapitalist üretim ilişkilerinde mekânın rolünü araştıran Harvey (1985) mekânı kapitalist sistemin sürekliliğinin sağlanması ve mekânın oluşan krizlerin çözümü yolunda sunduğu olanaklar bağlamında tartışmaktadır. Yazarın savına göre mekân (özellikle de kentsel mekân) kapitalist sistem içinde öncelikle sermaye döngülerinin sürdürülmesine ve bu döngüler arasında geçişler yapmaya olanaklar sağlamaktadır. Mekânı, üretim ve tüketim ilişkilerinin bir parçası olarak araçsallaştıran birinci döngü, yapısı gereği belirli zaman aralıklarında kitlenmekte, işlemez hale gelmektedir. Bu sorunlar (krizler) sermayenin inşaat etkinliklerini önceleyen ikinci döngüye geçmesine neden olmaktadır. İnşaat ve buna bağlı iktisadi etkinliklerin öncülük ettiği ikinci döngünün de sermaye üretimi ve dolaşımına sunduğu olanaklar kısıtlı olmakta, burada da kriz kaçınılmaz hale gelmektedir. İkinci döngünün sürdürülmesinde yaşanan sorunlar kâr amacı güden sermayeyi üçüncü döngüye geçmeye zorlar. Teknoloji yatırımları, araştırma-geliştirme uygulamaları ya da işgücünün kendini yeniden üretmesine yönelik yatırımlar ${ }^{4}$ bu kapsamda ele alınabilir. Üçüncü döngünün gerçekleşme süresi diğer iki döngüden çok daha uzundur ancak kâr etmek isteyen ve kâr getirici yatırımlar konusunda seçeneksiz kalan sermayenin başka bir yolu kalmamıştır. ${ }^{5}$

Harvey'e (1989) göre kent yöneticileri ve politikacıların da mekâna bakış açısı kapitalist düzenin baskılarıyla şekillenmekte ve bu durum mekânsal gelişim alternatifleri açısından yöneticilere çok da fazla seçenek sunmamaktadır . Bu bakış açısına göre kentler, giderek güçsüzleşen sanayi üretimi, turizm gibi hizmet etkinlikleri, yüksek seviyedeki finansal hizmetler ve devlet yatırımları için mücadele etmek dışında farklı iktisadi gelişim olanaklarına sahip görünmemektedirler. Bu olanaklarla bağlantılı kişi, kurum ya da kuruluşların ise önceki tartışmalarla bağlantılı olarak "güç odakları" oluşturup kentsel

\footnotetext{
${ }^{4}$ Tüketim potansiyeli önceki çevrimlerde kısıtlı hale gelen iş gücünün yeniden üretim yatırımlarıyla yeniden üretkenliğini kazanacağına, yeniden ekonominin bir parçası olacağına ve sermaye döngülerinin çalışmasına katkı sağlayacağına olan inanç nedeniyle sermayedarı bu yönde yatırım yapmaya yönlendirmektedir. Bu noktada Castells'in düşüncelerinin aksine sermaye ve emek arasındaki çıkar ilişkisi ortak bir noktada buluşmaktadır.

${ }^{5}$ Son kırk yıllık dönem içinde Türkiye' de üretim temelli iktisadi etkinliklerin sayısının ve hacminin giderek azalması, buna paralel olarak inşaat sektörünün ulusal ekonomideki rolünün giderek artması ve son on yıllık dönemde de inşaat sektöründe yaşanan sorunlarla da ilişkilendirilebilecek şekilde teknoloji ve AR-GE etkinliklerinin devlet tarafından farklı şekillerde desteklenmesi kar arayışındaki sermayenin farklı döngülere geçmesi konusunda örnekler sunmaktadır.
} 
gelişime yön vermesi benzer nitelikteki başka birçok araştırmanın konusu olmuştur (Logan ve Molotch, 1987).

Marksist şehircilik yazınının temel düşünürlerine atıfta bulunularak geliştirilen bu bölümde mekânın kapitalist sistem için hangi açılardan ve ne derecede önemli olduğu vurgulanmaya çalışılmıştır. Mekânın, nasıl şekilleneceği üzerine verilen mücadelelerle sürekli bir değişim içinde olduğu ve kapitalist sistemin kurumlarının değişimi kendi lehine gerçekleştirmek için verdiği çabanın olumsuzluklar oluşturduğu gerçeği günümüzde de sürmektedir. Mekân, kapitalist sistemin sürdürülebilmesi için yaşamsal öneme sahiptir. Sistem büyük bir çabayla mekânı algılayış biçimlerimizi ve bununla ilişkili olarak da mekâna müdahale yöntemlerimizi kontrol altında tutmak, kendini güvence altına almak istemektedir.

\section{Kapitalist Süreçlerde Mekân Üretimi, Mekânın Kullanımı ve Değerlenmesi}

Kapitalist sistemin sürekliliği açısından mekân önemli görevler üstlenmektedir. Sermayenin bir anlamda var oluşuna zemin hazırlayan ve varlığını sürdürmesini sağlayan mekân üzerine düşünceler de büyük oranda sermayenin bakış açısından, egemen sınıfın mekân üzerindeki çıkarlarını koruyacak şekilde ortaya konulmaktadır. Bu başlık altında mekân üretiminin nasıl gerçekleştiği ve hangi aşamalardan geçerek değer kazandığına ilişkin bir tartışma sunulacaktır. Tartışma mekânın üretimi ve değerlenmesi sürecini birbirini izleyen üç başlık üzerinden değerlendirmeyi amaçlamaktadır (Tablo 1.). Bölüm, yaygın olarak kullanılmakta olan taşınmaz değerleme yöntemlerine ilişkin eleştirel yaklaşımla sona erecektir.

Tablo 1. Araziden yapılı çevreye mekân üretimi ve değer oluşum süreci

\begin{tabular}{llll}
\hline Arazi & Tarla & Arsa & $\begin{array}{l}\text { Yapılı çevre } \\
\text { (parsel ve yapı) }\end{array}$ \\
\hline $\begin{array}{l}\text { ekonomik ve toplumsal } \\
\text { ilişkilerin dışında }\end{array}$ & tarımsal üretim & arazi kullanımı & $\begin{array}{l}\text { yapı ve parsel nitelik- } \\
\text { leri }\end{array}$ \\
\hline & özgün konum & $\begin{array}{l}\text { yapılaşma ko- } \\
\text { Şulu kararı }\end{array}$ & göreli konum avantaj1 \\
\hline
\end{tabular}

Arazi: Üzerinde bir yapı kararı geliştirilmemiş, gelişmeye açılmamiş toprak parçası

Arsa: Kentsel bağlamda bulunan, üzerine yapı yapılmak üzere ayrılmış, kentsel hizmetlerinden yararlanabilecek nitelikte toprak parçası

Yapılı çevre: Arsanın üzerinde arazi kullanım koşullarına uygun yapının gelişmesi ve kullanımı 


\section{Arazinin Değerlenmesi Süreci:}

Türk Dil Kurumu, arazi sözcüğünü yeryüzü parçası, yerey ya da toprak olarak tanımlamaktadır. Arazi, belki de mekânın en yalın hali, yeryüzünün bir parçası olarak, herhangi bir değer sistemiyle ${ }^{6}$ ilişkisi kurulmamış halde sadece bir toprak parçasıdır. Arazinin kapitalist sisteme eklemlenmesi, ekonomik ilişkiler düzeninde bir rol üstlenmesiyle gerçekleşmektedir. Bu eklemlenme arazi henüz imar koşulları taşımadan ve tarım gibi en temel üretim ilişkilerinin parçası olmadan, yalnızca gelecekte taşıyacağı kullanım değeri düşünülerek de gerçekleşebilir. Gerçekleşmeyen ancak olasılık olarak var olan kullanım değeri, arazilerin bir değişim değerine de sahip olmasına olanak tanır. "Arsa spekülasyonu" olarak bilinen kavram bu durumun bir örneğini oluşturmaktadır.

Arazinin değer kazanmasını sağlayan en önemli etken söz konusu toprak parçasının konumudur. Konum, arazinin ekonomik sistemlere yakınlığıyla ve bununla ilişkili olarak da erişim olanaklarından yararlanılmasıyla ilişkili değerlendirilebilir. Ancak ulaşım ilişkileri sağlandıktan, arazilere ulaşım olanakları geliştikten sonra toprakta gömülü olan potansiyeller (tarımsal değer, yer altı ve yer üstü kaynakları, vs.) değerlendirilebilecektir. ${ }^{7}$

Arazinin tarlaya yani tarım etkinliklerinin yapılabildiği bir toprak parçasına dönüşmesi, toprağın ekonomik ilişkilerle kurduğu en temel bağlantıyı oluşturmaktadır. Doğada var olan bir potansiyelin insan emeğiyle ortaya çıkarılması, topraktan edinilen ürünün temel yaşam koşullarını sağlamasının yanında artık üretimin ticaret gibi daha karmaşık iktisadi etkinliklere konu olması ise hem iktisatçıların hem coğrafyacıların ilgisini çeken bir konu olmuştur. Ricardo (1821) tarımsal arazilerin verimlilikleri üzerine yaptığı çalışmalardan yüksek verimlilikteki arazilerin, verimlilikleri oranında, düşük verimli arazilerden daha değerli olacağını varsaymıştır. Sonradan bu varsayımını (bu çalışma kapsamında da bir benzeri kullanılacak olan) emek-değer kuramıyla geliştirmiş ve arazilerin doğal verimliliğinin yanında üretimde harcanan emeğin de ürünün maliyet hesaplarına eklenmesi gerekliliğini vurgulamıştır.

\footnotetext{
${ }^{6}$ Buradaki sistem vurgusu sözcüğün genel anlamda kullanımına gönderme yapmaktadır. Yalnızca iktisadi ya da politik sistemlerin değil toprağa mekân anlamı katabilecek ve insan varlığıyla ilişkilendirilebilecek farklı değer sistemlerinin de söz konusu olabileceği unutulmamalıdır.

${ }^{7}$ Siyasal ilişkilere göre beliren ve sahip çıkılan topraklar (örneğin ülke sınırları) da sahip oldukları "siyasal değeri” büyük oranda parçası oldukları ya da olabilecekleri ekonomik ilişkilere borçludurlar. Ekonomik ilişkiler kapsamında değerleneceği düşünülmeyen toprakların (örneğin çöl düzlüklerinin) sahiplenilmesinin ya da sahiplenilmesi yönünde yapılacak çabaların düşük düzeyde olacağı varsayılabilirken ekonomik potansiyeli yüksek olan topraklar (örneğin su ya da yeraltı maden kaynağı barındıran topraklar) için verilen mücadeleler küresel ölçekte güç ilişkilerine konu olmaktadır.
} 
Von Thünen (1966) mekân temelli tarımsal üretim yaklaşımını ürün temelli bir yaklaşımla geliştirmiştir. Çiftçilerin ürettiği ürünlere ve alansal gereksinimlere, dolayısıyla bu ürünlerden elde ettikleri gelirlere göre yer seçtiğini gösteren Von Thünen, gözetilen ürünün pazara yakınlığı konusunu da modeline eklemiştir. Çalışmalarında, ürünlerin ortak olarak satışa sunulduğu bir merkezi yerleşime (pazar alanına) yakın olan arazilerin değerlerinin yüksek olacağını, bu merkezlerden uzaklaştıkça, artan ulaşım maliyetleri nedeniyle, bazı arazilerin ise değerlerinin düşeceğini öngörmüştür. Yeryüzündeki farklılıkların yok sayıldığı bu modelde belirli bir ürün gözetildiğinde, arazi fiyatlarının değişiminin merkezden çepere dairesel olarak azaldığı varsayılmaktadır. En yüksek kira teklifini verebilen üreticiler (örneğin süt üreticileri) merkeze daha yakın yerde konumlanabilirken, daha düşük teklifler getirebilen üreticiler (örneğin buğday üreticileri) giderek daha uzakta yer seçmek zorunda kalmaktadırlar (Şekil 1.).

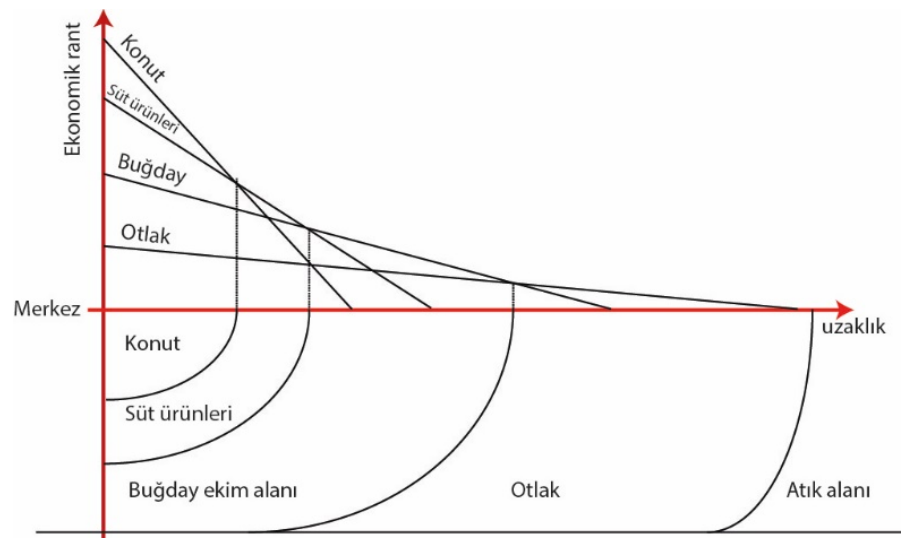

Şekil 1. Von Thünen'in Tarımsal Arazi Kullanımları Modeli

\section{Araziden arsaya geçişle edinilen değer:}

Toplumsal örgütlenme ve işbölümünün kapitalist ilişkiler içinde gelişmesi ve buna bağlı gelişen kentleşme, arazilerin değerlendirilmesi konusunda tarımsal üretim dişında başka pek çok gelişim, kullanım olanağının varlığını gündeme getirmiştir. Farklı bir açıdan yaklaşıldığında ise kapitalist ilişkilerin karmaşıklaşması ve bunu izleyen kentleşme dinamikleriyle birlikte mekânın yeni gelişim olanakları çerçevesinde kullanımının yaygınlaşması (tarımın gözden düşmesi) kapitalist sistemin devamı ve kapitalist ilişkilerin yeniden üretilmesi nedenleriyle zorunlu hale gelmiştir. 
Çoğunlukla kentsel işlevlerin etkisi altında kalan arazi, kentsel kullanımlar (arazi kullanımları) üzerinden yeniden üretilmeye başlamaktadır. Arazi üzerinde geliştirilen kullanım kararları ve beraberinde üretilen yapılaşma koşulları arazinin arsaya dönüşmesine olanak sağlamaktadır. ${ }^{8}$ Artık kentsel ekonominin bir parçası olan ve pek çok farklı kullanımla ilişkili halde var olan arsanın değeri atfedilen sorumluluklar düzeyinde artmaktadır.

Alonso (1964), Von Thünen'in (1966) tarım arazilerini temel alarak geliştirdiği yaklaşımının kentsel alan kullanımlarına da uyarlanabileceğini göstermiştir. Alonso' nun yaklaşımındaki temel varsayım, kentsel arsa sunumunun gözetilen zaman kapsamında sabit olmasıdır. Bu sabitlik içinde, farklı yatırımcların belirli bir konum üzerine yaptığı kullanım teklifleri ve bu teklifler çerçevesinde oluşan arsa değerleri, söz konusu konumda hangi kullanımın yer alacağını belirlemektedir. Teklifler, kullanımlar arasında bir rekabet oluşturmakta, kullanımların mekânsal örüntüsü de sunulan tekliflerin farklılaşan değerlerine göre değişmektedir (McDonald ve MacMillen, 2011:85). Birikim ekonomileri başta olmak üzere diğer başka pek çok durumu barındıran kent merkezi, pek çok kullanım için en cazip konum olmaktadır. Buradaki arazi fiyatları en yüksektir ve merkezden uzaklaşıldıkça arazi fiyatları azalmaktadır. Bunun bir sonucu olarak da birim alanda en yüksek kazancı sağlayan kullanımların (örneğin bankaların) kent merkezine yakın, birim alanda görece düşük kazanç sağlayan kullanımların (örneğin tarım ve sanayinin) ise kent merkezinden uzakta yer seçmesi beklenmektedir (Şekil 2.). ${ }^{9}$

\footnotetext{
8 Tablo 1'de görülebileceği üzere araziden arsaya dönüşen mekân değerleme sürecindeki en önemli aktör planlama kurumudur. Planlamanın kapitalist sistemin bir parçası mı, yoksa sisteme karşı duran bir yaklaşımın aracı mı olduğu tartışmaları hala sonuçlanmış değildir. Böyle bir tartışmayı çalışmanın sonuna bırakarak arazi kullanım kararlarının piyasa mekanizması koşullarında yer seçtiği varsayımıyla ilerleyeceğiz.

9 Park'ın 1920'lerin başında Chicago Sosyoloji Okulu çalışmaları çerçevesinde ürettiği Ortak Merkezli Yerler Kuramı çalışması Von Thünen'in modelini Alonso'nun çalışmasından yaklaşık 40 yıl kadar önce kentsel arazi kullanımları açısından değerlendirmeye almış olduğunu göstermektedir. Park çalışmasında ekonomik koşulların belirleyiciliğini kabul etmekte ve ekonomik olarak üstün olan kullanımların avantajlı yerleri seçtiğini söylemektedir. Ancak bu kabullenmeden sonra kullandığı ekoloji/biyoloji temelli kavramsal çerçeve yazarı Alonso ve Von Thünen'den farklılaştırmaktadır. Park, çıkarımlarında arazi değerleri ve getirimler (rantlar) gibi somut ölçütler kullanmak yerine biyolojik analojilerle kentsel kullanımların yer seçim süreçlerini ve konumlarının zaman içindeki değişimini irdelemiştir. Bu nedenle, Park’ın çalışmaları kent ekonomisi okulları içinde değerlendirilmemektedir.
} 


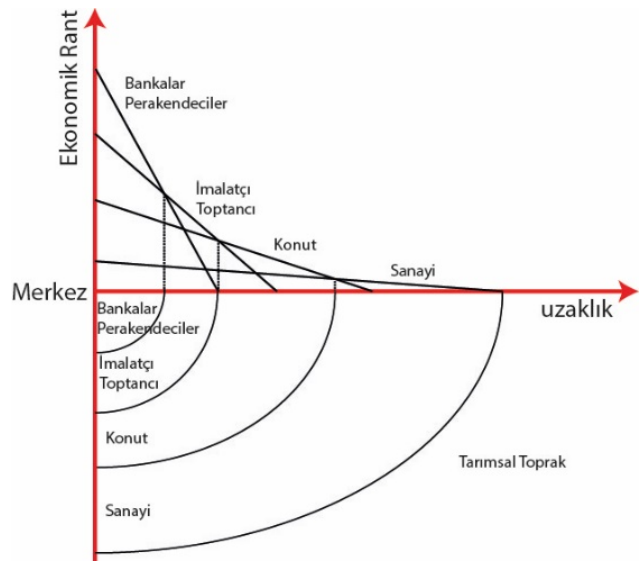

Şekil 2. Alonso'nun Teklif Edilen Rant Eğrisi Modeli

Alonso'nun (1964) tek merkezli modeli konuyu kavramsallaştırmak aç1sından değerli açılımlar sağlasa da gerçek yaşam koşulları çerçevesinde değerlendirildiğinde kısıtlı kalmaktadır. Ulaşım sistemlerinin gelişmesi ile kentsel hareketliliğin artması, kentlerin giderek çok merkezli bir yapıda gelişmesi ve farklı kullanımların, farklılaşan mekânsal gereksinimlere yol açması, belirli bir kullanım için oluşan değerin çok daha karmaşık süreçlerin sonucunda gerçekleştiğini göstermektedir. Örneğin bir sanayi tesisi için yalnızca kent merkezine yakınlık ya da ana ulaşım sistemiyle bütünleşme önemli olmamaktadır. İşücü maliyetleri, toprak dışındaki üretim girdileri (enerji ve sermaye), hammaddeye ulaşım, yerel bilgi birikimi, sendikalaşma düzeyi gibi pek çok etken üretim sürecini, dolayısıyla yer seçimini etkilemektedir. Ayrıca Alonso'nun modeli arazi kullanımıyla ilgili düşünce üretmesine rağmen yapılaşma koşullarıyla ilgili bir konuyu tartışmaya katmamıştır. Konut ve ticaret kullanımları gibi yapılaşma koşullarının (kat yüksekliği, taban alanı gibi) değeri belirleyici olduğu alanlar söz konusu olduğunda model oldukça kısıtlayıcı olmaktadır. Bu ve benzeri kısıtlar yapılı çevrenin niteliklerinin de tartışıldığı, arazinin değerlenmesi sürecine etki eden başka bileşenlerin de değerlendirildiği, ayrıntı düzeyi artan başka değerleme yöntemlerinin geliştirilmesini zorunlu kılmaktadır.

\section{Arsada yapılaşmanın gerçekleşmesiyle edinilen değer:}

Piyasa mekanizması içindeki rekabet her arazi kullanımını etkilerken arazi üzerindeki kullanıma ilişkin yapılaşma kararları da bu rekabette önemli olmaktadır. Bu durum, arazinin, üzerinde gerçekleşen kullanımla birlikte değerlendirilmesini ve değer tahmininin yalnızca konum üzerinden değil yapı- 
laşmaya ilişkin niteliksel farklılıklar üzerinden de ayrışmasını gerekli kılmaktadır. Günümüzde arsa ve üzerindeki yapı ile ilgili çalışmalar genel anlamda taşınmaz değerleme çalışmaları kapsamında incelenmektedir. ${ }^{10}$

Taşınmaz değerleme çalışmalarının temelini, taşınmazın piyasadaki değerini en doğru şekilde tahmin edilmesi oluşturmaktadır (Shapiro vd., 2013). Bu çalışmalar kapsamında arsanın edindiği değer piyasadaki değişim değeri üzerinden tanımlanmaktadır. Shapiro vd.'nin (2013, s.12) tanımlamasıyla:

“Üzerinde ilgi gelişen bir taşınmazın piyasa değeri, en basit şekliyle, belirli bir günde alma gücüne sahip olan insanların bu arsayı almak için ödemeye hazır oldukları para miktarıdır. Bu miktar o gün için ve o günkü piyasa şartları gözetilerek oluşan yaklaşık bir miktardır."

Bu açılamaya göre taşınmazın değerinin tanımlanmasında piyasa mekanizmaları, yani arz-talep dengesi belirleyicidir. Arzın taleple kesiştiği belirli bir zamandaki değer, taşınmazın değişim değeri olmaktadır. Bu modelde arz ve talebin elastik olduğu durumlarda fiyatın sabit kaldığı varsayılmaktadır. İki değişkenden birinin inelastik olması durumunda ise taşınmaz fiyatında değişimler olmaktadır. Talep inelastik olup, arz artarsa fiyat düşmekte, arz inelastik olup talep artarsa fiyat yükselme eğilimi göstermektedir. Böyle bir bağlam içinde, değerleme süreci, arz ile talep arasındaki dengeyi ve bu dengenin değişken yapısını en doğru şekilde anlamaya yönelmektedir.

Taşınmaz değerleme çalışmaları amaçlarına göre farklılıklar gösteren beş temel yaklaşımı barındırmaktadır. Karşılaştırma yöntemi bunlardan ilkidir. Piyasa mekanizmaları bağlamında ve arz-talep ilişkisi içinde gerçekleşen değerleme yöntemleri için en önemli girdi benzer bir ürün için yakın zamanda elde edilmiş değişim değeri bilgisidir. Bu bilgi temel alınarak söz konusu taşınmazın belirli bir andaki değeri belirlenmeye çalışılmaktadır. Karşılaştırma yöntemi kapsamında taşınmazın konumu, fiziksel durumu, mülkiyet durumu, kullanım amacı ve alım-satım zamanı da önemli ölçütler arasında bulunmaktadır (Shapiro vd., 2013, s.37-38). Eğer taşınmaz bir yatırım aracı olarak düşünülüyorsa gelir yaklaşımı tercih edilen ikinci yöntem olmaktadır. $\mathrm{Bu}$ yaklaşımda taşınmaza yapılan yatırım ve bu yatırımın geri dönüşünün ne zaman gerçekleşebileceğine ilişkin tahminler bu alanda yapılan değerleme çalışmalarının odağını oluşturmaktadır.

\footnotetext{
${ }^{10}$ Taşınmazın özelliklerini yansıtan bileşenlerin kapitalist sistemin karmaşı yapısıyla uyumlanması sonucunda taşınmaz değerleme çalışmalarının bazı üniversitede bölüm oluşturması ya da bir uzmanlık alanı olarak eğitime konu olması kaçınılmaz olmaktadır.
} 
Üçüncü yaklaşım olan gelişim yöntemi ise yukarıdaki iki yaklaşıma göre daha dinamik bir bakış açısıyla taşınmazın değerini tanımlamaya çalışmaktadır. Bu yaklaşım taşınmazın sürekli değişim içinde olduğunu varsaymaktadır. Taşınmazın şu andaki durumunun değil, gelecekte alacağı şekil ve kullanım değerlemeye konu olmaktadır. Dördüncü değerleme yöntemi olan kâr yaklaşımı ise arsanın kullanımı ve üzerindeki yapıya ilişkin beklenen brüt kâr üzerinden bir değerleme yöntemi sunmaktadır. Bu yöntemde de yeniden benzer kullanımlardan elde edilen kâr oranları referans alınmakta ve bu kâr oranlarının belirli bir süre daha sürmesiyle ilişkili olarak değerleme yapılmaktadır. Değerleme kapsamında kullanılan beşinci ve son yöntem giderler yaklaşımıdır. Bu yaklaşım, işletim geliri üretmeyen ve genellikle kamusal nitelikte olan kullanımların (dini tesis, okul, vs.) arazisiyle birlikte satılması söz konusu olduğunda kullanılmaktadır. Kullanımların yer aldığı arazinin fiyatı benzer arazi fiyatlarına referansla elde edilirken arazinin üzerindeki yapının yıkımı ve yeni bir yapının üretilmesi için gerekli olan maddi miktar da yine hesaplamaya konu olmaktadır. Hesaplanan giderlerin çıplak arazi fiyatından düşülmesiyle de taşınmazın değeri elde edilmektedir (Shapiro vd., 2013, s. 11).

Scarett (2008, s. 54) ise taşınmazlar üzerinde geliştirilen değerleme çalışmalarında farklı değişkenlere dikkat çekmektedir. Yazar, taşınmazın fiziksel özelliklerinin (arsanın konumu, topografik şartları, arsaya erişim, toprak yapısı ile yapıya ilişkin özellikler olan, arsa içindeki konumu, yapı malzemesi ve tekniği, yaşı, durumu), sözleşmeye ilişkin konuların (kiralama şartları, ödenecek kira miktarı, elde edilebilecek kira miktarları, süreler), kiracı profilinin ve olası harcamaların taşınmazların anlık değerinin belirlenmesinde önemli olduğunun altını çizmektedir. ${ }^{11}$ Wyatt (2013) ise değerleme çalışmalarına kullanıcı bakış açısını yerleştirmeyi amaçlamaktadır. Bu öneriye göre kullanıc beklentileri, gereksinimleri ve arzuları değerleme sürecine etki etmektedir. Bunlara paralel olarak kullanıcılara sunulan kredi olanakları, kullanıcıların bunlardan yararlanma şartları ve kullanıc birikimleri de değerlemenin bir parçası olabilmektedir. Son olarak, potansiyel alıcıların o araziyi almakla elde edeceği tatmin ve faydalar ve uzun erimde gerçekleşebilecek olumluluklar da Wyatt'ın (2013) önerdiği modelde değerlendirmelere katılmaktadır.

\footnotetext{
${ }^{11}$ Scarett (2008, s.12) taşınmaz piyasasını giderek daha çok oranda yatırım güdüsüyle şekillenen bir piyasa olarak görmektedir Bu çerçeveden bakınca değerleme uzmanı bir yatırım uzmanına dönüşmekte ve değerleme uzmanının amacı da belirli bir zaman aralığı kapsamında düzenli bir getirinin nasıl sermayeye dönüşeceğine ilişkin çalışmalar yapmak olmaktadır (Scarett, 2008: 43).
} 
Taşınmaz değerlemesi çalışmaları kapsamında değerlendirilebilecek, arazi kullanım kararlarını ve yapılaşma koşullarını bir bütün halinde içeren diğer bir çalışma alanı da "en yüksek ve en iyi kullanım çözümleme" (highest and best use analyse) yöntemidir. Taşınmaz Değerleme Sözlüğü'nün (2010) beşinci baskısında yer alan tanım şu şekildedir:

"boş bir toprak parçasının ya da mülkün mantıksal ve yasal çerçeve içinde, fiziksel olarak olanakl, finansal olarak uygulanabilir şekilde gerçekleşmesini sağlayarak en yüksek değerine ulaşacağı kullanımdır. Bu çözümleme çalışması, bir alanın uygulanabilir bir çerçeve içinde en uygun kullanım olanağıyla gerçekleşmesinin en yüksek değeri gerçekleştireceğini varsaymaktadır. Çözümlemenin odaklandı̆̆g zaman aralığı genellikle inşaatın gerçekleşmesini izleyen, kullanıma geçişle başlayan dönemi kapsarken bazı uygulamalarda yakın gelecek kapsamında yaşanacak değişiklikler de en iyi ve verimli kullanım çalışmalarını yönlendirmektedir."

Daha çok arazi üzerinde geliştirilecek kullanım kararına odaklanan bu yöntemde arazi, içinde bulunduğu bağlam kapsamında değerlendirilmekte ve bu kapsam içinde üretebileceği en yüksek değeri hangi kullanımla edinebileceği tahmin edilmeye çalışılmaktadır. Daha önceki çalı̧̧malar kapsaminda konum değişkeni üzerine yapılan vurgu bu değerleme yöntemi ile daha da ayrıntılandırılmış, araziyi odağına koyan ilişkisel bir çerçeve çizilmiştir. ${ }^{12}$

\section{Planlama Kurumunun Rolü:}

Taşınmaza ilişkin piyasa değerinin piyasa mekanizması tarafından tanımlanmasına yönelik yapılan vurgu, değeri oluşturan diğer etkenlerin göz ardı edilmesine neden olabilmektedir. Süreç içinde değerlenmeye konu olan şey, fiziksel olarak arazinin kendisi ya da orada yer alan yapılar değil arazi ve binaları, önce üretmeye sonra da kullanmaya izin veren yasal hakların değerlenmesidir. Yasal haklar, boş arazinin kullanım koşullarını ve arazideki yapılaşma şartlarını belirler ve kendi içinde farklı özgünlükler yaratır. Diferansiyel rant kapsaminda da yorumlanabilecek bu özgünlükler, yasal belgeler olan planlama kararları aracılığıyla değer oluşumunu olanaklı hale getirmektedir (Shapiro vd., 2013, s.3).

\footnotetext{
${ }^{12}$ Değerleme çalışmaları kapsamında parasallaştırılabilen pek çok değişkenin taşınmazın değerinin oluşumu sürecinde kullanıldığı görülmektedir. Shapiro vd.'nin (2012, s.3) de değindiği gibi taşınmaz değerlemesi alanında çalışan uzmanların pek çoğu toplumsal değer, estetik değer ve benzeri ölçülemeyen ya da parasallaştırılamayan değer kavramlarının da taşınmazın piyasa değerine etki ettiğini belirtmekte ancak bu konulara hesaplamalarında değinmemektedirler.
} 
Tartışmanın geldiği bu noktada mekânsal planlama kurumunun arazi üretimi ve değerlenmesi konusundaki rolüne değinmek yerinde olacaktır. Planlama, yalnızca mekân üzerindeki kullanım ve yapılaşma kararlarını etkilemesi açısından değil kullanımlar arasındaki ilişkileri belirlemesi açısından da önemli bir kurumdur. Planlama aracllı̆̆ıyla tanımlanan ilişkilerin bir zaman bağlamında, orta ve uzun erimde kurgulamasıyla da hem mekânın değerlenme süreci hem de kapitalist sistemin sürekliliği sağlanmaktadır. Bu nedenle Lefebvre (1991), sıklıkla atıfta bulunduğu planlama kurumunu, özellikle "tasarlanan mekânın" oluşmasındaki temel işlevi nedeniyle olumsuz bir biçimde vurgulamaktadır. Politikacıların (ve temsil ettikleri toplumsal sınıfların) aklında kurgu olarak beliren mekân başta şehir planclar olmak üzere farklı meslek gruplarınca (mimarlar ve mühendisler) tarafından uygulamaya yol gösterecek teknik bir dile tercüme edilerek (planlar ve projelerle) hayatın bir parçası haline gelmektedir. Planlamaya oldukça edilgen bir işlev yükleyen bu tür bir kavramsallaştırma, kurumu politik açıdan etkisiz, yalıtılmış, teknik bir eylem olarak kurgulamaktadır. Planlama kurumunun değerleme yazınına konu olması da böyle bir çerçevede gerçekleşmektedir. Böylelikle planlama kurumu;

- araziyi özel bir kullanıma yönlendirebilir, (boş tanımsız arsayı konut alanına dönüştürebilir),

- bir kullanımı başka bir kullanıma dönüştürebilir, (konut alanının ticaret alanina dönüşmesi),

- var olan kullanımların yoğunluğunu artırabilir, (emsal artışları, TAKS ve KAKS değişimleri)

- kullanıma ilişkin sınırlar koyar ya da değişimler sağlar, (bina okul olarak yapıldıysa okul olarak kalır, konuta dönüş̧ebilir)

- arazinin kullanımı üzerindeki yapılaşmaya sınırlar koyar, (kat yüksekliği 5 ile sinırlıysa bu geçilemez), ve

- yeni gelişim alanları yaratabilir, (yeni ofis kullanımlar için gelişim alanı sağlamak),

Planlamanın tüm bu olanakları yöneticilerin hizmetine sunması ve bu grupla kurduğu bağlılık ilişkisi, yöneticilerin siyasi ve ekonomik işlevi düşünüldügünde uzun soluklu bir tartışma alanı yaratmaktadır. Yöneticilerin nasıl bir politik ve iktisadi kompozisyon oluştuğu, hangi sınıfsal ilişkiler ağını temsil ettiği, ya da planlamanın mekân üretim süreçlerinde yöneticilerden 
bağımsız işleyebilecek özerk bir konumunun olup olamayacağı gibi sorular farklı bağlamlarda yanıtlanmaya çalışılmıştır. ${ }^{13}$

$\mathrm{Bu}$ bölüm altında sunulan değerlendirmeler kapitalist sistem içinde mekân üretimi, mekânın değerlenmesi ve değerleme süreçlerinin nasıl tanımlandığına örnek oluşturmaktadır. Sistem kendi avantajına olacak ve sürekliliğini sağlayacak bir kavramsallaştırma içinde süreçleri tanımlamaktadır. Arz-talep dengesine göre fiyatların belirlenmesi, oluşan fiyatlara göre arazi kullanımlarının yer seçmesi, değerlenen mekânın (ve taşınmazların) değerinin de gene arz-talep dengesi ve değişim değeriyle ölçülmesi tüm süreç çözümlemelerinin kısır bir döngü içinde gerçekleşmesine neden olmaktadır. Kapitalist sistemin kurumsal düzenlemeyi de yine kendi lehine olacak şekilde yapıp planlanma kurumunu güvence olarak görmesi, mekânsal süreçleri algılayış biçimlerini kısıtlanmasının yanında uygulamaya da sınırlar koymakta, mekânda mücadele alanlarını daraltmaktadır. Farklı bir bakış açısıyla yeniden yorumlanabilecek mekânsal süreçler yeni bakış açılarının, müdahale ve mücadele alanlarının gelişmesine olanak sağlayacaktır.

\section{Mekânsal değer oluşumu üzerine alternatif bir düşünce: Marx'ın Emek- Değer Kuramı}

\section{Emek-Değer Kuramı:}

Kapitalist sistem içinde mekân, kullanım değerinden çok değişim değeri üzerinden üretilmekte ve yine değişim değeri temel alınarak kullanılmaktadır. Bir başka deyişle, mekânın kullanıma ilişkin özellikleri ancak değişime, alım-satıma konu olunca gündeme gelebilmektedir. Bu da mekâna ve üzerindeki yapılara ilişkin değerlendirme süreçlerinde değerin değişim değeri, değişim değerinin de fiyat olarak karşımıza çıkmasına neden olmaktadır. Marksist şehircilik yazını, mekân üretimi ile meta üretimi arasındaki ilişkiyi

\footnotetext{
13 Lefebvre ve Castells gibi yazarlar yönetici sınıfının oluşumunda kapitalist sisteme ilişkin güç ve mücadele ilişkileri olduğuna vurgu yaparak yöneticilerin sermayedarlardan ya da bu kesimin çıkarlarını gözeten gruplardan oluştuğunu savunurlar. "Büyüme koalisyonları" fikrini ortaya atan Logan ve Molotch (1987) ise sermaye yanlısı elit grupların kentsel politikalara nasıl etki ettiklerine ve bu politikalar çerçevesinde mekânı ekonomik kazanç sağlama çabalarına nasıl alet ettiklerine vurgu yapmaktadır. Bu ve benzeri yaklaşımlara (Dear ve Scott, 1981 de eklenebilir) göre planlama, mekânı gündelik yaşam pratikleri aracılığıyla kendini yeniden üretmeyi amaçlayan, mekânın kullanım değerini önceleyen kentli kullanıcıların dilediği şekilde düzenlemenin bir aracı olmaktan çok uzaktır. Kapitalist sistem içinde mekân, planlama kurumunun meşrulaştırıcı işlemleri sayesinde, değişim değeri çevresinde örgütlenen uluslararası şirketlerin, yatırımcıların, finans kurumlarının, geliştiricilerin ve spekülatörlerin beklentilerini karşılayacak şekilde üretilmektedir (Clarke, 2014). Bu durumda gündelik yaşam birbirine zıt amaçlar güden iki mekânsal yaklaşımın mekâna hüküm etme mücadelesine tanık olurken. Mücadele ise denk güçlerin adil mücadelesinden çok, adaletsizliğin karakterini tanımladığı bir dönüşmüştür.
} 
sıklıkla vurgulamakta, aradaki benzerlikleri çelişkileriyle birlikte ortaya çıkarmayı amaçlamaktadır. Ne var ki mekânın metalaşma süreci ile kullanım ve değişim değeri gibi konularda sıklıkla başvurulan Marksist kuramın, değer oluşumuyla ilgili kısımları şehircilik alanında çok fazla irdelenmemiştir. ${ }^{14}$

Marx, değerin belirlenmesi sürecinin piyasa mekanizması içinde arz-talep dengesi esas alınarak yapılmasını eleştirmektedir. Düşünür, arz ve talebin pazar fiyatlarındaki geçici dalgalanmalardan başka bir şeyi düzenleyemeyeceğini savunur. Arz ve talebin yalnızca bir metanın pazar fiyatının nasıl olup da değerinin üzerine çıktığını veya altına düştügünü açıklayabileceğini, ancak değerin kendisine ilişkin bir bilgi oluşturmayacağını söyler (Marx, 2017, s.37). Bunun yanında Marx, arz ve talebin değil, ücretlerin metaların pazar fiyatları üzerinde etkisi olduğunu savunan düşünceye de ücret konusunun özüne inip bunu emekle değiştirmek gerektiğini savunarak karşıllk verir. Dolayısıyla metaların değeri, emeğin değeriyle belirlenmektedir (Marx, 2017, s.41). Bu tartışmalarla birlikte Marx'ın vurguladığı bir nokta ise değer ile fiyat arasındaki ilişkinin bütünselliğidir. Bu yaklaşıma göre değer ve fiyat ayrı sistemler tarafından oluşmamakta, sürekli bir ilişki içinde bulunmaktadırlar (Karahanoğulları, 2009, s.85).

Bir metanın değişim değerinden söz ederken o metanın diğer bütün metalar ile değiştirilirken aldığı orantısal nicelikler söz konusudur. İster altın ister ipek olsun bir metanın değerinin orantısal olarak aynı kaldığını düşünürsek değerin farklı değişim oranlarından ayrı ve bağımsız bir şey olduğu sonucuna varırız. Metalar arasındaki değişimleri gerçekleştirmek amacıyla da, altının ya da buğdayın birbirlerinden bağımsız ancak her ikisinin de ortak bir temsili olabilecek üçüncü bir ölçüye indirgenebilir olması gerekmektedir. Metaları, içerdikleri o özdeş ölçünün orantılarına göre birbirinden ayırt etmek gerekmektedir (Marx, 2017, s.43-4). Marx'a göre tüm metaların ortak noktası ya da kendi deyimiyle "toplumsal tözü", toplumsal emektir. Metalar yalnızca temsil ettikleri toplumsal emeğin niceliğine göre birbirinden ayırt edilebilirler. Düşünüre göre emeğin niteliği de bir ürünü elde etmek için harcanan emek-zaman ile ölçülebilmektedir. Bu da bir işçinin (verili toplumsal koşullar çerçevesinde, ortalama olarak ${ }^{15}$ kaç saat, kaç gün çalışarak o metayı ürettiğiyle ilişkilidir (Marx, 2017, s.45). Böylelikle metaların göreceli değeri;

\footnotetext{
14 Marx'ın 1865 yılında yaptığı sunuma ilişkin el yazmaları 1898 yılında “Ücret, Fiyat, Kâr” adıyla yayımlanmıştır. Marx daha sonra Kapital'de ayrıntılarıyla işleyeceği Emek-Değer Kuramı'nın ilk düşüncelerine bu eserde yer vermiştir.

${ }^{15}$ Emek değer kuramının önemli bir varsayımı da meta üretiminde kullanılan emeğin niteliğinin ve niceliğinin toplumsal olarak belirlendiğidir. Marx’a göre Toplumsal emek "verili bir toplumsal durumda, belli ortalama toplumsal üretim koşulları altında (teknolojik durum, yasalar, vs.), verili bir ortalama toplumsal yoğunlukta ve kullanılan emeğin belli bir ortalama beceri düzeyine sahip olduğu bir yerde, o metanın üretimi için gerekli emek miktarını betimler.” (Marx, 2017, s.49)
} 
"metalar için harcanan, her birinde somutlanan ve sabitlenen emeğin göreceli niteliği veya miktarı ile belirlenir. Aynı emek-zamanı içinde üretilebilen bă̆laşık meta miktarn eşittir. Ya da bir metada sabitlenen emeğin niceliği diğer metada sabitlenen emeğin niceliğine göre neyse, o metanın değeri de diğer metanın değerine göre odur."

Bu tartışma ücretlerin değeri oluşturduğu önergesinden oldukça farklıdır. Ücretler metanın değerini aşamazlar ancak bunun altında kalabilirler. Bir başka deyişle ücretler metaların değeriyle sınırlandırılmıştır ancak metaların değeri ücretlerden bağımsızdır (Marx, 2017: 47). Tartışma kâr oluşumuna da alternatif bir yaklaşım getirmektedir. Kârlar, metaların ortalama olarak gerçek değerleri üzerinden satıldıkları bir durumda, satış fiyatının metalarda somutlanmış olan emek miktarıla orantılı olarak belirlenmesiyle elde edilir (Desai, 2009: 54). Bir metayı üretmek için gerekli olan emek miktarına karşılık gelen ücretin tam olarak ödenmesi (ödenmiş emek) kâr edinilememesi durumunu doğurur. Bu ücrete karşılık gelen emek miktarı artırılırsa sömürü gerçekleşir ve kâr elde edilmeye başlar. Çünkü işçi bir miktar emeğini metaya aktarmıştır ve bu emeğin karşılığını alamamıştır (ödenmemiş emek). Meta üzerinde oluşan bu artı değer ise üreticiye kalarak kâr olarak adlandırılacak miktardır (Marx, 2017: 63-7). ${ }^{16}$

Bir metanın değişim değeri hesaplanırken o metayı üretmek için en son kullanılan emek miktarına, hammaddesinin elde edilmesi için daha önce kullanılmış olan emek miktarını ve bu emeğe yardımcı olan alet, aygıt, makine ve binalar için harcanan emeği de eklememek gerekir. Örneğin üretim araçları, yinelenen üretim sürecinde defalarca kullanılırlar ve bu araçların yıpranma payları üzerinden ortalama bir hesap yapılır. Üretilen metaya daha önce üretilmiş olan metalardan ne miktarda bir değerin aktarıldığı (örneğin araçların yıpranma payı) da gözetilen metanın değerinin hesaplanmasında kullanilır (Desai, 2009: 48).

Marksist iktisadi yaklaşımda tartışılagelen bu konulara çalışma çerçevesinde ayrıntılarıyla değinmeye olanak bulunmamaktadır. Çalışma kapsamında emeğin değerinin belirlenmesi ve emek ile piyasa fiyatları arasındaki ilişkinin tartışılması da söz konusu değildir. ${ }^{17}$ Ancak bu tartışmalar bizi emeğin, metanın değerini oluşturduğu bir sistemde, üretim sonucu elde edilen

\footnotetext{
${ }^{16}$ Piyasa mekanizması içinde, arz talep dengesi içindeki dalgalanmalardan oluşan kârlar ise geçicidir ve alıcıların bir sürelik bilgi eksikliğinden ya da kandırılmasından kaynaklanmaktadır. Böyle bir durumda sürekli bir kâr oluşumundan söz edilemez.

${ }^{17}$ Daha ayrıntılı tartışmalar için Karahanoğulları (2009) ve Akyüz (1980) incelenebilir.
} 
kentsel mekânın değerinin nasıl bir emekle ve emek kompozisyonuyla oluşturulduğu sorusunu yanıtlamaya yöneltmektedir.

\section{Emek-değer kuramı ve mekân:}

Şehircilik yazınında, özellikle de eleştirel şehircilik yazınında, mekânın kapitalist süreçlere konu olarak üretilmesi ve metalaşması konusuna sıklıkla vurgu yapılmakta, pek çok alanda Marksist düşünce sistemiyle paralellikler oluşturulmaktadır. Ancak kurulan tüm ilişkilere rağmen mekânsal değerin oluşum süreçleri konusunda Marksist düşünceden beslenen kaynak bulmak neredeyse olanaksızdır. Oysa mekânı bir meta gibi değerlendirmek ve bir metanın üretimi gibi mekânın üretimindeki değer kompozisyonunu görmek ilginç açılımlar sağlamaktadır.

Emek-değer kuramının mekâna uyarlanması farklı ölçeklerde gerçekleşebilir. Örneğin, planlama yoluyla üretilen mekânın (araziden arsaya dönüşümün) değerini arsanın değişim değeri ya da özgün konumu üzerinden düşünmek çok kısıtlayıcı olmaktadır. Bir arsanın değeri toplumsal, ekonomik ve siyasi ilişkiler sistemi içinde ve bu sistemin mekâna yansıması soncunda oluşmaktadır. Bir başka deyişle mekân, kentsel, toplumsal emek süreçleriyle şekillenmekte ve değerlenmektedir. Geleneksel değerleme sistemlerinin ön plana çıkardığı "konum” kavramı tüm bu karmaşık ilişkiler sistemini değişim değerine, oradan da piyasa fiyatlarına indirgenmektedir. Bu indirgeyici düşünce şekli, "kamu yararı" adına yürütülen planlama çalışmalarının zaman zaman adaletsizlik üretmesine zemin hazırlamakta, planlama kurumuna ilişkin pek çok toplumsal tartışmayı da beraberinde getirmektedir.

Mekânın toplumsal emeğin bir ürünü olduğunu savunan yaklaşımın sunduğu olanaklar, mekânsal pratikleri algılayışımızı da değiştirmektedir. Örneğin, planlama kararı olarak arsalara getirilen arazi kullanım ve yapılaşma kararlarının planlama alanının teknik ussallığı içinde geçekleştiği varsayılmaktadır. Bu ussallık ise kendisini kamu yararı kavramına, planlama ve şehircilik ilkelerine sı̆̆ınarak meşrulaştırmaktadır. Ancak ne kamu yararı kavramı ne de şehircilik ilkeleri arsa sahibi iki kişiden birinin yoğun yapılaşma koşulu bağlayıcılığında konut+ticaret alanı hakkı edinmesi ile diğerinin düşük yapılaşma koşulu altında kentsel rekreasyon alanı hakkı edinmesi arasındaki çatışmayı ve çelişkiyi çözememektedir. Gerek avantajlı olan birinci koşul, gerekse görece olumsuz gözüken ikinci koşul, arsa sahiplerinin iradesinden bağımsız olarak toplumsal, ekonomik ve siyasal ilişkiler sistemi içinde, kentsel toplumsal emeğin sonucu olarak üretilmiştir. Planlama kurumundan beklenen, toplumsal üretim süreçlerinin farkına varıp, toplumsal ilişkiler çerçevesinde değerlendirmeler yapıp, en uygun kullanım ve yapılaşma kararlarını 
geliştirmesidir. ${ }^{18}$ Yerel veya merkezi yönetimden ise, sahip olduğu ideoloji ve adalet anlayışı çerçevesinde, toplumsal ilişkiler sonucunda oluşan eşitsizlikleri yeniden dağıtım mekanizmalarıyla gidermesi beklenebilir. ${ }^{19}$

Araziden arsaya geçiş sürecinde oluşan değer ve bunun emekle ilişkisi konusundaki tartışmaları derinleştirmek olanaklıdır. Ancak çalışma ampirik olarak test ettiği başka bir ölçeğe, arazi üzerindeki taşınmazın değerlenmesi konusuna odaklanmaktadır. Emek-değer kuramının bu sürece uygulanmasıyla piyasa fiyatlarının ve değişim değerlerinin gizlediği pek çok boyutun ortaya çıkarılması amaçlanmaktadır.

\section{Yöntem ve Alan Çalışması}

\section{Yöntem:}

Çalışma yapı üretim sürecindeki emek etkinliklerine odaklanarak piyasa fiyatı ve değişim değeri çerçevesinde tanımlanan ve bu alanın dişına çıkmaya olanak vermeyen değerleme yöntemlerinin ötesine geçen bir yaklaşım geliştirmeyi amaçlamaktadır. Emeğin, değer oluşumunun (dolayısıyla fiyatın) ayrılmaz bir parçası olması gerekliliğinin hatırlanmasıyla değer belirleme süreçlerinin dışında kalmış pek çok aktörün emeğinin (bilgi birikimi, tekniği, becerisi, vs.) sürece olan katkısı da yeniden tartışmaya açlabilecektir.

Taşınmaz üretiminde yer alan aktörlere odaklanan çalışma, yasalar çerçevesinde sorumluluk alanları belirlenmiş meslek gruplarına ve bunların yapı üretim sürecinde harcadıkları emek zamana yönelik bir çerçeve içinde gerçekleşmektedir.

Çalışma, kendi somut sonuçlarını üretebilmek için soyut bir çalışma alanı tanımlamaktadır. Bu nedenle çalışmanın var olan taşınmaz değerleme yöntemlerine alternatif geliştirerek emek temelli ve emekle ilişkili yeni bir fiyat

\footnotetext{
${ }^{18}$ Teknik bir yaklaşımın egemen olduğu bir süreç gibi görünen planlama uygulama alanı doğası gereği ideolojiktir. Planlama kurumunun toplumsal ilişkileri yorumlama biçimi pek çok değer yargısıyla şekillenmektedir. Bu nedenle farklı ekonomi politik bağlamlarda farklı niteliklerde şehircilik ve planlama yaklaşımları oluşmakta, yine farklı şekillerde belirlenebilecek kamu yararı kavramlarının varlığı ise kaçınılmaz olmaktadır. Bağlam bağımlı gelişen planlama uygulama alanının değerlendirilmesinin statik bir atıf alanı yerine gözetilen bağlam içindeki eylem tutarlılığına göre yapılması toplumsal adaleti sağlama açısından belki çok daha doğru olacaktır.

1915 Eylül 2020 günü Resmi Gazete'de yayınlanarak yürürlüğe giren İmar Planı Değişikliğine Dair Değer Artış Payı Hakkındaki Yönetmelik ile toplumsal ilişkilerden kaynaklanan değer artışlarından (buna teknik toplumsal gerekçelerle meşrulaştırılabilen plan tadilatları da eklenebilir) yalnızca arazi sahiplerinin değil yerel ve merkezi yönetimlerin de pay alabilmesine olanak sağlamıştır. Yönetimlerin edindiği payın topluma ne oranda geri dönebildiği ve toplumsal adaletsizlikleri giderebildiği konusu çözülmemiş bir sorun alanı olarak karşımızda durmaktadır.
} 
belirleme önerisi sunma amacı bulunmamaktadır. Benzer şekilde, özel üretim koşulları gerektiren yapı üretim tipleri de (yüksek riskli alanlarda gerçekleşen yapılar ya da özel mimari projeye göre geliştirilen yapılar) çalışma kapsamının dışındadır. Tanımlanan soyutluk alanı çerçevesinde, verili toplumsal koşullar çerçevesinde, farklı mekânsal konum ve bağlamların çözümleme üzerinde farklılaştırıcı bir etki yapacağı düşünülmemiştir.

Özetle çalışma, kentsel alanda standart olarak tanımlanabilecek konut üretim süreçlerine odaklanmaktadır. Ankara kentine bağlı Bahçelievler Mahallesi kentsel alanında, gerçekleşmesine sıklıkla tanık olunan, en çok $500 \mathrm{~m}^{2}$ yapı alanı büyüklügüne sahip, küçük yükleniciler tarafından gerçekleştirilen, betonarme inşaat tekniğiyle yapılan (3B kategorisinde, birinci sınıf lüks betonarme konut inşaatı) konut inşaatları arasından seçilen beş örnek bu çalışma kapsamında değerlendirilmiştir. Tüm projelerde Bahçelievler bölgesinde geçerli olan Kat Rejimi Planları (Şekil 3.) yapılaşma koşulları geçerlidir. Bu koşullar uyarınca, ana caddelerin çevresindeki yapıların beş katlı, diğer yerlerdeki yapıların ise dört katlı olması öngörülmüştür. Çalışma kapsamında değerlendirilen projelerin ana yolların kenarında bulunmamasına ve zemin hariç dört kat yükseklik koşulunu sağlamasına özen gösterilmiştir. Çalışma, her projeyi temsil eden ve projenin tümü üzerinde bilgi sahibi olan üç adet yüklenici (inşaat mühendisi) ve iki adet teknik uygulama sorumlusu (inşaat mühendisi) ile yapılan yarı-yapılandırılmış görüşmelerden elde edilen bilgilerin derlenmesiyle gerçekleşmiştir.

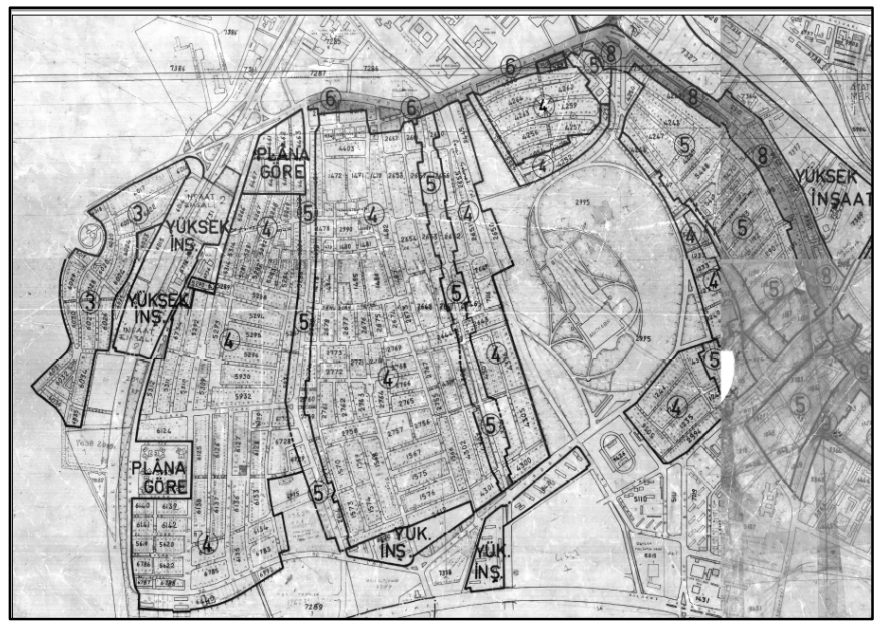

Şekil 3. Bahçelievler Kat Rejim Planı, (Çankaya Belediyesi, 2014) 
Görüşmeler sonunda elde edilen bilgiler kullanılarak konut üretim süreci kendi içinde anlamlı parçalara ayrılmış, süreçte yer alan aktörler tanımlanmış ve aktörlerce projeye aktarılan emek miktarları bir insanın çalıştığı toplam saat ya da gün üzerinden değerlendirilmiştir.

\section{Araştırma Bulgulart:}

Görüşmelerden derlenen bilgiler doğrultusunda yapı üretim sürecinin iki aşamada gerçekleştiği anlaşılmaktadır. Koordinatların belirlenmesi ve aplikasyon çalışmalarının yapılması konut üretim sürecinin "proje aşaması" olarak adlandırılabilecek ilk bölümünü oluştururken süreç, konutun fiziksel üretiminin gerçekleştiği ve "uygulama aşaması" olarak nitelendirilebilecek ikinci aşama ile sonlanmaktadır.

\section{Proje Aşaması, Aktörleri ve Emek Alanlar:}

Proje aşaması konut üretim sürecinin ilk adımıdır. Bu aşamada başta mimari proje olmak üzere, bunu temel alan mekanik projesi, elektrik projesi, statik projesi, jeolojik etüt projesi ve peyzaj projeleri gerçekleşmektedir. Projelerin sinıflanması ve projelerden sorumlu aktörler yasalarca belirlenmiştir. Parseldeki yapılaşmaya ilişkin yerel yönetime iletilecek dosyada, yasada adı geçen proje kalemlerinin ve bu projelerle ilişkili uzmanların imzasının bulunması zorunludur. Değinildiği üzere projelerin yasal müellifleri ilgili konuların uzmanı olan mimar ve mühendislerdir. Ancak projelerin yapım aşamasında pek çok tekniker de görev alabilmektedir. Proje aşamasından sorumlu olan aktörler ve temel etkinlik alanları aşağıdaki tabloda (Tablo 2.) sunulmuştur.

Tablo 2. Konut üretim sürecinin yasal aktörleri ve sorumlu oldukları projeler

\begin{tabular}{ll}
\hline Proje konusu & Yasal Aktörler \\
\hline Mimari Projesi & Mimar (yasal sorumlu), teknikerler \\
\hline Mekanik Projesi & Makine Mühendisi (yasal sorumlu), makine teknikeri \\
\hline Elektrik Projesi & Elektrik mühendisi (yasal sorumlu), elektrik teknikeri \\
\hline Statik Projesi & İnşaat mühendisi (yasal sorumlu), inşaat teknikerleri \\
\hline Jeolojik Etüd & Jeoloji mühendisi gerekli durumlarda jeofizik mühendisi (yasal sorumlu), \\
Projesi & jeoloji teknikerleri \\
\hline Peyzaj Projesi & Peyzaj mimarı (yasal sorumlu), tekniker \\
\hline Modelleme & Çizim-modelleme teknikerleri (yasal olarak zorunlu değil) \\
\hline
\end{tabular}

Görüşmelerden edinilen bilgiler çerçevesinde beş projeden ikisinde (Proje 1 ve Proje 5) yapı üretiminin uzmanı olan mühendis ve mimarların emek ve 
bilgi birikiminden neredeyse hiç yararlanılmadığı, gerekli belgelerin üretiminde yalnızca teknikerlerin emeğine başvurulduğu ve yasal zorunluluk gereği ancak imza aşamasında uzmanların sürece dahil edildiği görülmüştür. Araştırmaya konu olan beş projeden ikisinde (Proje 2 ve Proje 3) ise "tip proje" uygulamasının tercih edildiği, taban alanı ve kattaki daire sayısına göre tasnif edilmiş proje envanterinden standart projelerin seçildiği, dolay1sıyla alana özel herhangi bir görüş geliştirilmeden önceden çizilmiş bir projenin uygulamaya esas alındığı katılımcılar tarafından belirtilmiştir.

Sonuç olarak yapı üretiminin proje aşamasında, emek yoğun bir etkinlik alanı oluşturulmadığı, oluşan emek alanında ise kullanılan emeğin büyük çoğunluğunun yasalarca tanımlanan uzmanlarca değil, teknikerlerce gerçekleştiği görülmüş̧tür.

İncelenen beş proje içinde yalnızca Proje 4'te mimarlar ve mühendisler projeleri üreten uzmanlar olarak görev üstlenmişlerdir. Proje 5 'te ise teknikerlerin emek yoğunluğunda da olsa mimar ve mühendislerle iş paylaşımının gerçekleştiği görüşmüştür. Diğer projelerde, tekniker çalışanların emek oranlarının ise görece daha yüksek olduğu belirlenmiştir.

Mimar-mühendisler ile teknikerler arasındaki emek farkı ortalamalar üzerinden de açığa çıkmaktadır. 1,6 a.s. ${ }^{20}$ olan mimar mühendis emek ortalaması teknikerler söz konusu olduğunda yaklaşık 3 kat artarak 4,5 a.s. olmaktadır. Tip proje uygulamasının olduğu Proje 2 ve Proje 3 'de ise hem teknikerlerin hem de mimar-mühendis uzmanların harcadıkları emek miktarı düşüş göstermektedir (Tablo 3.). Özetle, bina yapım sürecinin proje aşamasında tüm mimar-mühendis ve teknikerlerin emekleri toplandığında ortalama 42,78 a.s.'lik bir düşünsel emek harcandığı görülmektedir.

Tablo 3. Proje aşaması aktörleri ve adam x saat (a.s.) emek dağılımı

\begin{tabular}{lllll}
\hline & Proje 1 & & & \\
\cline { 2 - 5 } & adamxsaat & & adamxsaat & \\
\hline Mimari Projesi & Mimar: & 1 & Tekniker: & 15 \\
\hline Mekânik Projesi & Makine Müh: & 0,5 & Tekniker: & 6 \\
\hline Elektrik Projesi & Elektrik Müh.: & 0,3 & Tekniker: & 5 \\
\hline Statik Projesi & İnşaat Müh.: & 1 & Tekniker: & 9 \\
\hline Jeolojik Etüd Projesi & Jeofizik Müh.: & 0,5 & Tekniker: & 6 \\
\hline Peyzaj Projesi & Peyzaj Mimarı: & 0 & Tekniker: & 3 \\
\hline Modelleme & Mimar: & 0 & Tekniker: & 3 \\
\hline & & & & \\
\hline & Proje 2 & & & \\
\hline & adamxsaat & & adamxsaat & \\
\hline
\end{tabular}

${ }^{20}$ Emek ölçüsü $=1$ adam x 1 saat (a.s.) 


\begin{tabular}{|c|c|c|c|c|}
\hline Mimari Projesi & Mimar: & 0,1 & Tekniker: & 9 \\
\hline Mekanik Projesi & Makine Müh: & 0,3 & Tekniker: & 5 \\
\hline Elektrik Projesi & Elektrik Müh.: & 0,5 & Tekniker: & 6 \\
\hline Statik Projesi & İnşaat Müh.: & 1 & Tekniker: & 7 \\
\hline Jeolojik Etüd Projesi & Jeofizik Müh.: & 0,5 & Tekniker: & 5 \\
\hline Peyzaj Projesi & Peyzaj Mimarı: & 0 & Tekniker: & 2 \\
\hline \multirow[t]{3}{*}{ Modelleme } & Mimar: & 0 & Tekniker: & 3 \\
\hline & \multicolumn{4}{|l|}{ Proje 3} \\
\hline & adamxsaat & & adamxsaat & \\
\hline Mimari Projesi & Mimar: & 0,2 & Tekniker: & 12 \\
\hline Mekanik Projesi & Makine Müh: & 0,5 & Tekniker: & 9 \\
\hline Elektrik Projesi & Elektrik Müh.: & 0,5 & Tekniker: & 8 \\
\hline Statik Projesi & İnşaat Müh.: & 1 & Tekniker: & 9 \\
\hline Jeolojik Etüd Projesi & Jeofizik Müh.: & 0,5 & Tekniker: & 7 \\
\hline Peyzaj Projesi & Peyzaj Mimarı: & 1 & Tekniker: & 1 \\
\hline \multirow{3}{*}{ Modelleme } & Mimar: & 0,5 & Tekniker: & 4,5 \\
\hline & \multicolumn{4}{|l|}{ Proje 4} \\
\hline & adamxsaat & & adamxsaat & \\
\hline Mimari Projesi & Mimar: & 11 & Tekniker: & 3 \\
\hline Mekanik Projesi & Makine Müh: & 6 & Tekniker: & 2 \\
\hline Elektrik Projesi & Elektrik Müh.: & 5 & Tekniker: & 2 \\
\hline Statik Projesi & İnşaat Müh.: & 9 & Tekniker: & 3 \\
\hline Jeolojik Etüd Projesi & Jeofizik Müh.: & 4 & Tekniker: & 2 \\
\hline Peyzaj Projesi & Peyzaj Mimarı: & 0,5 & Tekniker: & 0,5 \\
\hline \multirow[t]{3}{*}{ Modelleme } & Mimar: & 0 & Tekniker: & 0 \\
\hline & \multicolumn{4}{|l|}{ Proje 5} \\
\hline & adamxsaat & & adamxsaat & \\
\hline Mimari Projesi & Mimar: & 2 & Tekniker: & 14 \\
\hline Mekanik Projesi & Makine Müh: & 2 & Tekniker: & 9 \\
\hline Elektrik Projesi & Elektrik Müh.: & 1,5 & Tekniker: & 8 \\
\hline Statik Projesi & İnşaat Müh.: & 3 & Tekniker: & 10 \\
\hline Jeolojik Etüd Projesi & Jeofizik Müh.: & 2 & Tekniker: & 8 \\
\hline Peyzaj Projesi & Peyzaj Mimarı: & 0 & Tekniker: & 2 \\
\hline Modelleme & Mimar: & 0 & Tekniker: & 2 \\
\hline
\end{tabular}

\section{Inşaat aşaması, aktörleri ve emek alanları:}

İnşaat aşaması konut üretim sürecinin ikinci aşamasıdır. Bu aşamada yapılan işler kabaca hafriyat, temel atımı, zemin ve duvar yalıtımı, kaba betonarme inşaat (demir, kalıp, duvar, tesisat işleri gibi) ve ince inşaat (boya, zemin döşeme gibi) işleri şeklinde ayrilabilir. Fiziksel emeğin çok daha fazla harcandığı bu ikinci adımda emek yoğun etkinliklerin çoğunu ustalar üstlenmektedir. Görüşmelerden derlenen ve her projede ortak bulunan bilgilere 
göre, yaklaşık 20 kalem işi, çoğunlukla çalışma alanının eğitimini resmi koşullarda almamış ancak deneyimle yetişmiş ustalar gerçekleştirmektedir.

İnşaat aşaması ustaların uzmanlık alanlarının tanımlandığı alt iş kollarına ayrılabilmektedir. Demirci ve kalıpçların çalıştı̆g 1 kaba inşaat üretimi, sıva, alçı, elektrik ve su tesisatı yapımı, kapı-pencere montajı ile boyama inşaat aşamasınin temel etkinlikleridir. Bu etkinlikler arasında en fazla emek-zamanı demirci ve kalıpçılar harcamaktadır. Görüşmelerden edinilen bilgiler ış1ğında bir inşaatta çalışan ve demirci ile kalıpçıdan oluşan ekibin (ortalama beş kişi) 5 x 101 a.g. ${ }^{21}$ emek harcayarak zemin artı dört katlı bir binanın kaba inşaatını bitirebildiği anlaşılmaktadır. Sonrasında gerçekleşen sıva işleri için ise ortalama 88 a.g., alçı işleri için de ortalama 41,8 a.g. emek harcanmaktadır. Elektrik ve su tesisatlarının döşenmesi konusunda ise ortalama 5 a.g. emek gerekmektedir. İmalat sürecinin inşaat aşamasından bağımsız gerçekleştiği kapı-pencere montajı işleri için ise ortalama 9,9 a.g. emek gerektiği belirtilmiştir (Tablo 4.).

Tablo 4. İnşaat aşaması aktörleri ve adam x gün (a.g.) emek dağılımı

\begin{tabular}{lcccccc}
\hline & Proje 1 & Proje 2 & Proje 3 & Proje 4 & Proje 5 & ortalama \\
(adamXgün) & & & & & & \\
\hline Kaba inşaat & 100 & 95 & 105 & 110 & 95 & 101 \\
\hline Siva & 85 & 90 & 90 & 100 & 75 & 88 \\
\hline Alçı & 40 & 42 & 38 & 47 & 42 & 41,8 \\
\hline Elektrik ve su tesisatı & 4,5 & 5 & 6 & 5 & 4,5 & 5 \\
\hline Montaj & 8,5 & 10 & 9 & 12 & 10 & 9,9 \\
\hline & & & & & TOPLAM & 245,7 \\
\hline
\end{tabular}

Özetle, verili koşullar çerçevesinde, Ankara, Bahçelievler'de zemin artı dört kattan oluşan ve yaklaşık 220 metrekare taban alanlı ve katta iki dairenin bulunduğu, betonarme bir binanın inşaatı aşamasında yaklaşık 650 a.g. fiziksel emek harcanmaktadır.

Yapının oluşması ile inşaat aşamasının bitişi büyük oranda sonlanmaktadır. Sürecin tamamen sona ermesi için yapının bulunduğu ilçedeki ilgili yerel yönetimin gerekli kontrolleri yaparak yapının teknik ve yasal koşulları sağladığından emin olması gerekmektedir. Bu aşamayı geçen yapılar için inşaat sürecinin resmen bittiği belgelenir. Bundan sonra, ilgili yerel yönetim konutta

\footnotetext{
${ }^{21}$ Emek ölçüsü = 1 adam x 1 gün (a.g.)
} 
yerleşim sürecinin başlayabileceğini belirtir ve yapıyı kullanıma açar. Bu son adımla birlikte kentsel arsa üzerinde yapı üretim süreci de sona erer. ${ }^{22}$

Özetle, standart sayılabilecek bir yapının üretim sürecini düşünsel emeğin yoğun olduğu proje yapım aşaması ve fiziksel emeğin yoğun olduğu inşaat aşaması olarak ikiye ayırmak olanaklıdır. Yapı üretiminin proje aşamasında toplamda yaklaşık 43 a.s. düşünsel emek harcanırken bunun yaklaşık dörtte birinin (\%26) mimar ve mühendisler tarafından geri kalan büyük çoğunluğunun (\%74) ise teknikerlerin emekleriyle gerçekleştiği görülmektedir. Yap1 üretiminin inşaat aşamasında gerçekleşen yaklaşık 650 a.g. işin ustalar ve kalfalar aracılığıyla yapıldığı görülmektedir. Yapı üretim sürecinin tümüne bakılarak elde edilen düşünsel emek ile fiziksel emek arasındaki oranın emeksaat üzerinden binde sekiz olması (8/1000) ise düşünsel etkinliklerin süreç içindeki öneminin ne kadar az olduğunu kullanılan toplam emek oranında göstermesi nedeniyle önemlidir.

\section{Çıkarım ve Tartışmalar}

Yukarıda sunulan emek temelli çözümleme piyasa mekanizması içinde yalnızca değişim değeri gözetilerek kurgulanan değer ve fiyat yaklaşımlarına kıyasla çok daha geniş bir bakış açısıyla yorum yapmaya olanak sağlamaktadır. Emek-değer kuramı çerçevesinde önerilen çözümlemeyle yapı üretim sürecini yalnızca "üretim faktörlerinin" ekonomik bileşiminin bir sonucu olmaktan çıararak, üretim sürecindeki en temel belirleyicilerden biri olan emeğe odaklanmaya olanak sağlamıştır. Bu durumun da farklı emek bileşenleri üzerinden, yapının üretim sürecinin çözümlenmesi konusunda yeni aç1lımlar sağladığı görülmüşsür. Emek temelli bu yaklaşım, yapının değişim değerini artırmaya yönelik öneriler sunmak yerine, üretilen yapının teknik ve estetik değeri ile yapının bağlamıyla ilişkisinin daha kuvvetli biçimde nasıl kullanılabileceği üzerine çeşitli düşünceler geliştirilmesini de olanaklı kılmaktadır. Bu düşünceler, yazının son bölümünde yapı güvenliği, yapı estetiği, teknik olanaklar-yenilikçilik ve çevresel bütünsellik başlıkları altında tartışılacaktır.

\footnotetext{
${ }^{22}$ Katılımcılar, yasaların tanımladığı şekilde projeleri denetlemekle sorumlu olan ve yapı denetim firmalarında çalışan mühendis ve mimarların, inşaata ilişkin temel projelerden sorumlu olan mühendis ve mimarların çoğundan çok daha fazla mesai harcadığını özellikle vurgulamaktadırlar. Ancak yapı denetim süreci konut üretim sürecine olan dolaylı katkısı nedeniyle araştırmaya dahil edilmemiştir.
} 


\section{Yapı Güvenliği}

Konut üretimi konusundaki tartı̧maların temelinde güvenlik konusu bulunmaktadır. Güvenlik konusunda yeterlilikler sağlanmadığı sürece diğer tartışmalar büyük oranda anlamını yitirecektir. 1999 yılında gerçekleşen Gölcük ve Düzce Depremleri Türkiye'yi maddi ve manevi olarak derinden etkilemiş, yapı güvenliğine ilişkin çeşitli yasal düzenlemelerin geliştirilmesi konusunda karar vericileri yönlendirmiştir. 2001 yılında Resmi Gazete'de yayımlanarak yürürlüğe giren 4708 sayılı Yapı Denetimi Hakkında Kanun, Türkiye'de yapı denetimi konusunda önemli tedbirlerin alınmasına olanak sağlamıştır. Kanun çeşitli düzenlemelerle gelişerek, eksikliklerine rağmen bugün de yapı üretim sürecinin önemli bir parçası olmayı sürdürmektedir.

Konut üretim süreçlerinin Emek-Değer Kuramı üzerinden incelendiği bu çalışma kapsamında yapı denetim firmalarının etkinlikleri inceleme dışında tutulmuştur. Ancak gerçekleştirilen tüm görüşmelerde, katılımcılardan edinilen bilgiler doğrultusunda görülmüştür ki yapı denetim firmaları ve bunlara bağlı çalışan uzmanlar görevlerini ciddiyetle yapmaktadırlar. İncelenen beşörnekte de, denetim sürecinde görevli ve sorumlu olan mühendis ve mimarların raporlarını aracı (tekniker) kullanmadan ürettikleri ve hazırlık sürecinde uzun mesailer harcadıkları bilgisi verilmiştir. ${ }^{23}$

Türkiye'nin afetlere açık yapısı nedeniyle yapı denetimi ya da daha somut bir ifadeyle yapı güvenliği konusunda politika üreticilerin, sermayedarların, yüklenicilerin, üreticilerin ve bir oranda da tüketicilerin uzlaşması sonucunda yapı denetim sisteminin kurgulandığı şekilde çalıştığını ve gelişme halinde olduğunu söylemek olanaklıdır. Ancak çalışma kapsamında sıklıkla eleştirilen piyasa temelli değer yaklaşımları, bu uzlaşıyı da sürekli olarak zorlamaktadır. Yapıların kullanılabilir alanlarına ilişkin tartışmalar (örneğin; emsale dahil olan/olmayan alanlar, emsal artış talepleri, vs), kâr artırımına yönelik güdü ve özellikle de kriz zamanlarında azalmakta olan kâr oranları yapı güvenliği konusunda sağlanan uzlaşıyı ve teknik gereklilikleri sürekli bir şekilde esnetilme baskısı altında tutmaktadır. Denetimi sağlayan aktörler arasındaki ilişkileri şeffaflık ve hesap verebilirlik ölçülerinde geliştirmek güvenli yapı üretiminin temelini oluşturmaktadır.

\footnotetext{
${ }^{23}$ Bu durum, bir yandan, yasalar tarafindan yetkilendirilen ve yapı üretim sürecinden dışlanamayacak olan denetim görevlilerinin harcadıkları emek-zamana karşı aldıkları ücretlerin adil olmasıyla ilişkilidir. Diğer yandan yasalar, denetim görevini üstlenen teknik uzmanların sorumluluğunu da kesin bir şekilde tanımlamakta ve çalışanların bu sorumluluk çerçevesinde hareket etmesini sağlamaktadır.
} 


\section{Yapı Estetiği:}

Yapılara ilişkin olarak güvenlikten sonra en çok tartışılan konu estetiktir. Yapıların, özellikle de konut yapılarının niteliksizliği ve tekdüzeliği mimari ve planlamaya ilişkin tartışma alanlarında sıklıkla söz edilen konulardır. Bu çalışma kapsamında sonuçlanması olanaklı olmayan bir estetik tartışmasına girilmeyecektir. Ancak konut üretim süreçlerinde yapının estetik kalitesini doğrudan etkileyecek düşünsel emeğin (mimari, peyzaj, mühendislik, vs.) oranının düşüklüğü dikkat çeken bir durumdur. İncelenen projeler kapsamında zaten çok düşük oranlarda gerçekleşen düşünsel emek, bazı projelerde "tip proje" uygulamasının gündeme gelmesiyle daha da sinırlı halde kalmaktadır. Bağlamdan ve değişen şartlardan, taleplerden bağımsız üretilmiş olan tip projelerin yarattı̆̆ estetik bütünsellik, üzerine düşünülmesi gereken bir tartışma alanı sunmaktadır.

Çalışma kapsamında görüşülen katılımcıların sözü edilen estetik tartışmaları büyük oranda "maliyeti artıran işlevsiz eklentiler" olarak yorumladığı gözlemlenmiştir. Bunun yanında projelere konu olabilen estetik değerlerin ise projelerde sermayeleri oranında söz sahibi olan kişilerin (genellikle yüklenicilerin ve sermayedarların) estetik kaygılarını projelere yansıması şeklinde olduğu belirtilmiştir. Böyle kısıtlı bir bağlam içinde estetik olarak algılanan konuların bina boyası, dış cephe kaplaması ve bahçe korkuluklarından öteye geçmediği ise katılımclar tarafından vurgulanan bir başka konu olmuştur.

Mimarların, peyzaj mimarlarının ve şehir plancıların temel tasarım eğitimine konu olan ve eğitimleri süresince uyguladıkları; kütle-boşluk ilişkileri, denge, simetri-asimetri, yapı-doğa ilişkisi, yapı-yapı ilişkisi gibi başta görsel olmak üzere tüm duyuları etkileyebilecek, daha geniş kapsamlı bir estetik yaklaşımın, üretilen projelerde gözetilmediği, daha doğru bir ifadeyle bu bilgilerin projelere yansitılabilmesine olanak verecek bir emek-zaman yaklaşımının yapı üretim sürecinde yer edinemediği ortaya çıkmaktadır. Benzer şekilde kullanıc tercihleri, sürdürülebilirlik ya da akıllı yapı sistemleri gibi güncel tartışmaların da projelerde yer bulamadığını söylemek olanaklıdır. Estetiğin bina makyajına, kullanıcının ise potansiyel alıcıya indirgendiği, sürdürülebilirlik ve akıllı sistemler gibi kavramların da ancak pazarlamaya konu olabilecek oranda projeye dahil edilebildiği bir süreç içinde yapı üretiminin üstün bir (estetik ya da işlevsel) değer üretmesini beklemek gerçeklikten çok uzak kalmaktadır. 


\section{Teknik Olanaklar ve Yenilikçilik:}

Günümüz koşullarında kentsel alanlarda yığma-kagir yapıların sayısı giderek azalırken betonarme yapıların sayısı ise giderek artmaktadır. Bu değişimdeki en önemli belirleyicilerden biri daha önce tartışlan güvenlik konusu iken diğer bir değişkenin yapım tekniğindeki gelişmeler ve bunun yapım maliyetlerine etkisidir. Günümüzde, sağladığı diğer tüm olumlu koşulların yanında betonarme yapıların yapım maliyetleri yığma-kagir yapıların yapım maliyetlerine oldukça yaklaşmış durumdadır (Bostancıoğlu ve Birer, 2004).

Ancak teknolojinin yapı üretiminde kullanımına yönelik önemli veriler sunan taşıııı sistem, yapıya ilişkin olarak irdelenebilecek teknik alanlardan yalnızca biridir. Yapının kullanımını olanaklı hale getiren diğer sistemler; su, elektrik, havalandırma, ş̧ıklandırma ile yangın söndürme ve acil tahliye sistemleri ise değişime ve yaratıı uygulamalara konu olabilecek diğer uygulama alanlarıdır.

Yapılan görüşmelerde, yapı sistemlerine ilişkin sorulan sorulara katılımcıların tamamı kullanılan malzemeler üzerinden yanıtlar vermişlerdir. Örneğin su sistemi gözetildiğinde, demir boruların yerini PVC temelli boruların aldığı, ahşap çerçeveli tekli cam sistemlerinin yerine ise PVC ya da alüminyum doğramalı çoklu cam sistemlerinin geçtiği bilgisi verilmiştir. Konut üretim süreçlerinde yapıya ilişkin sistemlerdeki yenilik kapasitesi ve yaratıcılık alanlarının tümü malzeme kültürüne indirgenmiş durumdadır. Sistemlerin yeniliği, gelişmişliği, etkinliği ve özgünlüğü yalnızca kullanılan malzemeler üzerinden tartışılmaktadır. Örneğin bir katılımcı kendisinin piyasada pahalıya satılan ama kaliteli olan su boruları kullandığını söylerken diğer bir firma kablolarını en kalitelisinden seçtiğini belirtmekle yetinmiştir.

Konut projelerinde daha yaratıcı ve etkin sistem çözümlerinin kullanılması düşüncesine yönelik verilen tepkiler ise "böyle bir arayışa gerek olmadığı" yönündedir. Bu görüşe göre her yeni arayış "konut üretim süresini olumsuz etkileyecek, büyük olasılıkla maliyeti de artıracaktır. Bunun yanında yeni uygulamalar teknik koşulların değişmesini gerekli kılarken firmaları sürdüremeyecekleri bir sürece girmeye de zorlayarak yok olmalarına neden olacaktır". Bir başka değişle ezberler bozulacaktır ve kimse bu ezberin bozulmasını istememektedir. Piyasa mekanizması ve bu çerçevede gözetilen kâr oranları bir yandan düşünsel emeğin uygulamadan kopmasına neden olmakta diğer yandan yapı üretirken nitelikli değer oluşturmanın ve sürdürülebilirlik gibi bir amaç uğruna üretmenin de önünde engel oluşturmaktadır. 


\section{Mekânsal Bütünsellik ve Süreklilikler:}

Önceki başlıklarda ele alınan konular çoğunlukla mimar ve mühendislerin bilgi alanlarına yönelik çıkarımları kapsıyordu. Bu bölümdeki tartışma ise planlama ve kentsel tasarım alanıyla doğrudan ilişkilidir.

Yapı üretim sürecinde düşünsel emeğin oranının azlığı yapının çevresiyle kurduğu ilişkiyi de etkilemektedir. Yapının üretim süreci ve piyasaya sunulması genellikle odaklanılan yapıyı merkezine koyan, yapının çevresindeki açık alanla ve diğer yapılarla ilişkisini görmezden gelen bir süreçtir. Altyapı bağlantıları açısından kurulan zorunlu ilişkisellik dışında yapı, büyük oranda çevresinden bağımsız gelişmektedir. ${ }^{24}$

Yapıyı çevreleyen binaların kütleleri ve farklı bileşenleri (balkonlar, pencereler, otopark, araç ve yaya girişleri, açık alanlar, bahçeler, vs.) aracılığıyla üretime konu olan yapının tasarımına farklı referanslar sunmaktadır. Üretilmekte olan yapının bu verileri dikkate alarak tasarlanması, görsel ve estetik bütünlügün yanı sıra işlevsel kazanımlar da sağlayacaktır. Bunun yanında tasarımda, açık alan ve yeşil alanların dikkate alınmasıyla sonradan oluşacak yapılar için de yeni referanslar oluşturması, daha geniş ölçekte açık/yeşil alan sürekliliğini sağlayacaktır. Birleşerek büyüyen, gelişen ve yayılan açı/yeşil alanlar, yeşil ve mavi koridorların oluşmasına, açık alan sistemlerinin ve kamusal alanların gelişmesine, ekolojik olumlulukların artmasına, yaya dolaşım sisteminin gelişmesine ve kamusal kentsel değerlere erişimin kolaylaşmasına olanak sağlayacaktır.

Günümüz koşullarında ancak toplu konut grupları ve siteler kapsamında gerçekleşebilen süreklilikler (yaya, yeşil alan, yapı, vs. sürekliliği), bu çalışmaya da konu olan, kentsel alanda gerçekleşen, tekil konut projelerinde büyük oranda kaybolmaktadır. Bunun yanında kendi kapsamları içinde sistematik bir süreklilik oluşturan yapı alanları da bir araya geldiklerine yeniden kopukluklar meydana gelmekte, yapı adası ölçeğinde gözlenen süreklilikler yapı adaları arasındaki ilişkilerde izlenemez olmaktadır (Şekil 4.).

\footnotetext{
${ }^{24}$ Kimi zaman bölgelere, yerelliklere özgü yönetmeliklerle yapının çevresiyle uyumlanması sağlanmaya çalışılmaktadır. Bodrum'da üretilen yapıların beyaz renkle boyanması buna bir örnek olarak verilebilir.
} 


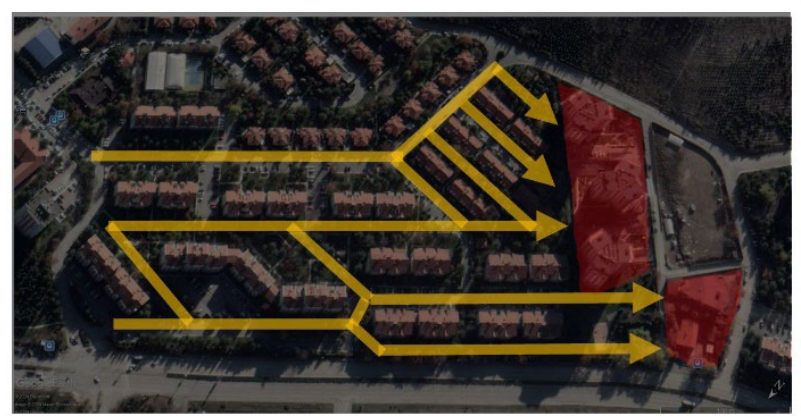

Şekil 4. Bir toplu konut alanındaki mekân süreklilikleri ve başka bir toplu konut alanının bu süreklilikleri önlemesi. Mimari, kentsel tasarım ve planlama alanlarında uzmanların etkin biçimde yer aldıkları, sağlanan sürekliliklerin sarı oklarla gösterildiği, sol tarafta yer alan Ankara, Konutkent II Sitesi 1994 yılından bu yana kullanımdadır. Şeklin sağ tarafında yer alan ve kırmızı ile gösterilen Royal City yerleşkesi ise 2010 yılında kullanıma açılmıştır. Farklı bir konut dokusunun yok edilmesiyle sonuçlanan plan değişiklikleriyle ve değişim değeri önceliğiyle inşa edilen Royal City, mekân üretme, kullanma ve süreklilikler açısından kısıtlı olanaklara sahiptir. (Yazarın mekânsal gözlemleri ve Google Earth, 2020)

\section{Sonuç}

Kapitalist sistem kendi dinamikleri çerçevesinde yalnızca mekânı şekillendirmekle kalmayıp aynı zamanda mekân algımızın kapitalist sistemin bakış açısıyla gelişmesine de neden olarak sistemin tüm kırılganlıklarına rağmen devam etmesini sağlamaktadır.

Çalışma, eleştirel mekân tartışmalarında sıklıkla kullanılan mekânın "üretimi" ve "metalaşması" gibi Marksist kavramların yine Marksist bir yöntem çerçevesinde geliştirilmesini, böylelikle üretilen ve metalaşan mekânın değerlenme sürecinin de emek-değer kuramılla birlikte nasıl ele alınabileceğini araştırmak amacıyla kaleme alınmıştır. Çalışma farklı ölçeklerde mekân ve mekânsal değer üretimine odaklanmış, bu süreçleri, bir anlamda parçalayarak değişim değeri ile piyasa fiyatları arasında kaybolan aktörlerin süreç içindeki katkılarının değerlendirilmesine olanak sağlamıştır. Bu değerlendirme sonucunda mekân üretimiyle ilişkili olarak çok daha geniş bir bakış açısı elde edilmiştir. Kentsel ölçekte daha adil bir mekânsal düzen oluşumundan, parsel ölçeğinde daha güvenli ve nitelikli mekânlar elde edilmesine kadar pek çok konuda yeni müdahale alanları belirlenebilmiştir.

Değişim değeri ve fiyat odaklı süregelen yaklaşımlar mekânsal süreçlere (üretim, değerlenme ve değerleme) yönelik pek çok önemli konunun “örtü altında" kalmasına neden olmakta, nitelik ve yenilik yoksunu mekânların üretimine zemin hazırlamaktadır. Sunulan çalışmanın, bu örtüyü kaldırarak 
öncelikle yeni tartışma alanlarının gelişmesine sonra da nitelikli mekân üretim süreçlerinin yaygınlaşmasına öncü olması amaçlanmıştır.

Çalışma kapsamında sunulan, mekân üretimi ve değerlenmesi süreçlerinde kullanılan Marksist Emek-Değer Kuramı farklı çalışma koşullarında uygulanabilecek bir yöntem olarak okuyucularla paylaşılmıştır. Yaklaşımın bu çalışmada uygulandığı şekliyle ya da geliştirilerek farklı bağlamlarda (farklı kentler ve ülkeler), farklı mekânsal ürünler (toplu konut, alışveriş merkezi, altyapı, vs.) gözetilerek kullanılması çalışma kapsamında ulaşılan sonuçlardan farklı sonuçlar üretecektir. Değişen teknolojik, toplumsal, ekonomik ve siyasal bağlamların farklı sonuçlar üretmesi sunulan çalışmanın sonuçlarıyla çelişmeyeceği gibi metinde vurgulanan temel savı destekler niteliktedir. Ancak bundan daha önemlisi, önerilen yöntemin uygulama alanının derinleşmesi ve yaygınlaşması toplumsal mekân algısının da değişmesine katkıda bulunacaktır. Böylelikle toplumun, kapitalist sistemin kısıtları d1şında bir bakış açısı geliştirerek mekânı görmesi ve değerlendirmesi daha da olanaklı hale gelecektir. 


\title{
Extended Abstract
}

\section{Application of Marxist Labour Theory of Value on the Processes of Production and Valuation of Urban Space}

\author{
Ahmet Burak Büyükcivelek \\ ORCID: 0000-0002-1760-1107
}

Within the capitalist system, space is seen as a reflection and a product of power relations. It is also with the help of the capitalist system's space production capacity that its social and economic relations persist. For this reason, capitalism put a particular emphasis on space. The capitalist system only enables the discussion on and over space from a very limited perspective to keep "the veil" hiding contradictions, injustices, and other space production possibilities. Although mainstream approaches do not challenge the provided perspective, alternative thought systems, especially Marxism, is utilised to overcome this limit. Discussions over "the social production of space", "commodification of space", and "spatial-territorial justice" evolved around this alternative perspective. Such research areas contribute to understanding social and economic relations of production and open up possibilities to challenge them. The work presented here aimed to move beyond the concepts of "production of space" and "commodification of space" that dominate the majority of discussions carrying the intention to relate Marxism and space. To this end, Marx's Labour Theory of Value is utilised to develop a new perspective on spatial analysis.

The paper has been structured based on five sections.

The first part of the paper analysed Marxist approaches that consider space an essential part of the capitalist system. The ideas of three prominent Marxist thinkers, Lefebvre's, Harvey's and Castells' ideas, were discussed, emphasising each authors' significance of contribution. Lefebre's conceptualisation of the "spatial triad" enabled the reader to identify the fundamental power relationships that shape space production processes. The role of the 
state, technocratic viewpoints and the perspective of users reflected in this identification. Castells, sharing Lefebvre's social production of space point of view, concentrated on the urban social movements. For him, such movements have to be considered challenges over the space and define whether space is shaped concerning capitalists' aims or workers' needs. Harvey's contribution to the discussion focused on the importance of space in the continuation of the capitalist system. Circuits that Harvey identified enabled the reader to understand how space is indispensable for reproducing the capitalist economic system, especially when its crisis-prone nature is taken into account.

In the second part, discussions on the production of space have been developed to analyse mainstream approaches that deal with the formation of land rents and valuation of land with a particular focus on urban areas. The transformation of terrain (from agricultural land to the property and the built environment) has been analysed with the Labour Theory of Value perspective. Parallel to this, discussions on the valuation of land have been initiated regarding the early works of Ricardo and Von Thünen. More contemporary approaches on land valuation, especially about the valuation of urban lands, have discussed land valuation techniques in practical use. As a conclusion of this section, it is revealed that approaches focusing on land rents and valuation of urban lands are emphasising the exchange values. It is either in the form of products obtained from the land or value obtained directly after the exchange that this emphasis is realised. Concerned approaches that inherit the frame of market mechanisms posed limitations on our understanding of urban land economics and its components and obscuring the possibilities of intervention on urban land that contribute to different aspects of urban spatial structure from quality to aesthetics.

The third sections concentrated on the presentation of Marx's Labour Theory of Value. At the theoretical level, Marx was concentrated on the production of commodities. To determine their prices, Marx underlined the utilisation of wages or, more accurately, the amount of labour spent in the production processes instead of prices. This emphasis moved the discussions on valuation away from supply and demand mechanisms and located it within the production process. Following this, the discussion tried to be applied to the valuation of space, considered a "produced" commodity. To overcome the limitations of valuation approaches that emphasise exchange values, the idea of social production of urban space has been applied to the debate. 
The fourth part of the paper focused on applying the Labour Theory of Value to the case area of Bahçelievler District in Ankara. At Bahçelievler District, five, almost identical, urban renewal projects have been selected. Rather than identifying the value of buildings based on the Labour Theory of Value, the research intended to reveal actors and their works that produce the product, which is the building for this case. The production process of these projects was analysed in two sections being the project and construction processes. Each process has further been decomposed into differentiated work responsibilities and actors contributing to these works. Actors' contribution has been quantified based on their labour measured either in the form of man $x$ hour or man $x$ day, depending on the nature of work. In sum, it was observed that capitalists (contractors or investors) were trying to minimise the labour cost as much as possible to decrease the construction cost of the buildings and maximise profit levels that will be obtained after the sale of the flats. The intention of lowering the effect of labour processes in the projects resulted in significant limitations. Despite slight variations in projects, a possible contribution of intellectual labour during the project phase minimised while exploitation of physical labour during the construction phase intensified.

The fifth and the final part of the paper was devoted to the discussions and possibilities that can be obtained with the implication of the Labour Theory of Value to determine values of housing projects of different sorts. Market-based approach guiding the valuation process emphasises given on exchange, and supply-demand relationships contributed to the continuation of capitalist system and betterment of some sections of the society. However, analyses indicate that the conventional approaches are also the sources of some problems. With the opening provided by applying the Labour Theory of Value into the building production process, it has become possible to intervene in the process from different dimensions including structural safety, building aesthetics, innovation and technology, environmental/spatial integrity and spatial continuities.

\section{Kaynakça/References}

Akyüz, Y. (1980) Emek-değger teorisi ve nitelikli işgücü sorunu. Ankara: Ankara Üniversitesi Siyasal Bilgiler Fakültesi Yayınları.

Alonson, W. (1964) Location and land use: Toward a general theory of land rent. Cambridge: Harward University Press.

Bostancıoğlu, ve E., Birer, E. (2004) Farklı yapım sistemleri ve konut maliyetleri. İstanbul: İTÜ, 2. Ulusal Yapı Malzemesi Kongresi ve Sergisi. 
Castells, M. (1974) Monopolville: L'entreprise, l'etat, l'urbain. Paris: Mouton.

Castells, M. (1978) City, class and power. New York: Macmillan.

Castells, M. (1984) The city and the grassroots: A cross-cultural theory of urban social movements. Los Angeles: University of California Press.

Clark, E. (2014) Good urban governance: Making rent gap theory not true. Geografiska Annaler, Series B, Human Geography, 96(4), 392-395, doi: 10.1111/geob.12060.

Desai, M. (2009) Marksist iktisat teorisi. Ankara: Eflatun Yayınevi.

Havey, D. (1973) Social justice and the city. London: Edward Arnold.

Havey, D. (1985) The urbanisation of capital. New York: Blackwell.

Harvey, D. (1989) From managerialism to entrepreneurialism: The transformation in urban governance in late capitalism. Geografiska Annaler, Series B, Human Geography, 71(1), 3-17.

Karahanoğulları, Y. (2009) Marx’ın değeri ölçülebilir mi? 1988-2006 Türkiye'si için ampirik bir inceleme. İstanbul: Yordam Kitap.

Logan, J.R. ve Molotch, H. (1987) Urban fortunes: The political economy of place. Berkeley and Los Angeles University of California Press.

Lefebvre, H. (1968) Le droit à la ville. Paris: Editions Anthropos.

Lefebvre, H. (1991) The production of space. Oxford: Blackwell.

Low, S. (2017) Public space and the public sphere: The legacy of Neil Smith. Antipode, 49, 153- 170. doi: 10.1111/anti.12189.

Marx, K. (2017) Ücret, fiyat, kâr. İstanbul: Kor Kitap.

Marcuse, P. (2015) Gentrification, social justice and personal ethics. Int. Journal of Urban Regional Planning, 39, 1263-1269. https://doi.org/10.1111/14682427.12319

McDonald, J.,F. ve McMillen, D.,P. (2011) Urban economics and real estate: Theory and policy (2nd edition). Hoboken: John Wiley and Sons.

Merrifield, A. (2002) Dialectical urbanism. New York: Monthly Review.

Mitchell, D. (2003) The right to the city: social justice and the fight for public space in America. New York: Guilford.

Ricardo, D. (1821) The principles of political economy and taxation. London: Dent.

Scarett, D. (2008) Property valuation: five methods (2nd. Edition). London: Routledge.

Scott, A.J. ve Dear, M. (1981) Urbanisation and urban planning in capitalist society. London: Routledge.

Shapiro, E., v.dğr. (2013) Modern methods of valuation (11th edition). London: Routledge.

The Dictionary of Real Estate Appraisal (5th Edition) (2010) Chicago: Appraisal Institute.

Von Thünen, J.,H. (1966) The isolated state. Oxford: Pergamon Press.

Wyatt, P. (2013) Property valuation: 2nd edition. New York: Wiley-Blackwell. 